\title{
Assessing the effects of multiple environmental stressors on zooplankton assemblages in Boreal Shield lakes since pre-industrial times
}

\author{
Anna M. DESELLAS ${ }^{1,2) *}$, Andrew M. PATERSON ${ }^{2)}$, Jon N. SWEETMAN ${ }^{1,3)}$ and John P. SMOL ${ }^{1)}$ \\ ${ }^{1)}$ Paleoecological Environmental Assessment and Research Laboratory (PEARL), Department of Biology, Queen's University, \\ Kingston, Ontario, K7L 3N6, Canada \\ ${ }^{2)}$ Ontario Ministry of the Environment, Dorset Environmental Science Centre, 1026 Bellwood Acres Road, Dorset, Ontario, P0A \\ 1E0, Canada \\ ${ }^{3)}$ Parks Canada, Western and Northern Service Centre, 145 McDermot Avenue, Winnipeg, MB, R3B 0R9, Canada \\ *e-mail corresponding author: anna.desellas@ontario.ca
}

\begin{abstract}
Zooplankton communities in Boreal Shield lakes of south-central Ontario, Canada, have become increasingly exposed to the effects of multiple anthropogenic stressors, such as declines in calcium (Ca) and total phosphorus (TP) concentrations, shifts in predation regimes, and climate warming. The paleolimnological approach provides an effective means of examining cladoceran zooplankton communities prior to the onset of these major environmental stressors and assessing how the increasing impacts of these stressors have affected zooplankton community composition. We examined the chitinized remains of cladocerans from recent and pre-industrial (pre- 1850s) sediments in 42 oligotrophic lakes from south-central Ontario and compared these assemblages using ANOSIM and SIMPER. Differences in cladoceran assemblages since pre-industrial times were related to five environmental variables that significantly influence cladoceran community composition in surface sediments. These included measured physical (depth), chemical [Ca, pH, sulphate, dissolved organic carbon (DOC)], and biological (fish community biomass) limnological variables. Two changes were recorded in the cladoceran species assemblages of the study lakes. The first was a significant increase in the ratio of pelagic species compared to littoral species over time in most lakes which we cannot attribute to any measured environmental variable with certainty but it likely represents a multiple stressor effect. The second was changes in relative abundances of daphniid cladocerans in several lakes since pre-industrial times, which we attribute to the interactive effects of several environmental stressors, including: differences in Ca availability within our lakes, resulting in decreased abundances of daphniids over time in lakes with lower Ca levels; long-term increases in DOC concentrations, which may provide refuge for daphniids from visual predators; and long-term declines in TP concentrations which may contribute to the dominance of species that are more efficient grazers, such as daphniids. Overall, this study provides field-based evidence that the modern-day cladoceran communities in south-central Ontario lakes are different than they were prior to human settlement in the region, and therefore these paleolimnological data provide a long-term, historical component to contemporary cladoceran datasets and an extended perspective on how multiple environmental stressors have impacted aquatic organisms from Boreal Shield lakes.
\end{abstract}

Key words: Paleolimnology, Cladocera, zooplankton, Ontario, Boreal Shield, multiple stressors

\section{INTRODUCTION}

The cumulative effects of multiple anthropogenic stressors have resulted in long-term changes in water quality and biota in lakes on the Canadian Shield (Yan et al. 2008a). More than three decades of data from lakes near the Ontario Ministry of the Environment's Dorset Environmental Science Centre document changes that include declines in total phosphorus (TP: Hall \& Smol 1996; Eimers et al. 2009) and calcium concentrations (Ca: Jeziorski et al. 2008; Molot \& Dillon 2008), changes in predator assemblages (Yan et al. 2001), invasive species introductions (e.g., Yan et al. 2002), and alterations in concentrations of dissolved organic carbon (DOC) (Zhang et al. 2010). Variations in climate are also evident in these lakes through a lengthening of the ice-free season (Futter 2003), and alterations in phytoplankton and zooplankton composition (Paterson et al. 2008; Rusak et al. 2008). These stressors may act individually or in concert. For example, increases in mean annual cladoceran size in Canadian Shield lakes in recent decades may be a response to climatically-mediated declines in TP (Yan et al. 2008b).

Zooplankton are an important link in the aquatic food web and are valuable indicators in assessments of environmental change (e.g., Keller \& Yan 1998). Changes in zooplankton community structure are often highly correlated with lake water chemistry (e.g., pH, Sprules 1975; Roff \& Kwiatkowski 1977; Ca: Wærvågen et al. 2002; E.P., Jeppesen et al. 2003; lake colour: Wissel, Boeing \& Ramcharan 2003; climate: Gyllström et al. 2005). Long-term data on crustacean zooplankton size and taxonomic composition collected from lakes in Muskoka-Haliburton (Ontario, Canada) since the 1980s show that the zooplankton communities of these lakes have changed over the past two decades. In a recent study, Yan et al. (2008b) examined trends in crustacean zooplankton abundance, body size, species richness and composition in eight intensively-studied lakes between 
1980 and 2003. Although total species abundance (number of animals $\mathrm{L}^{-1}$ ) did not change over time, there has been a general trend of increasing species richness in three lakes and increasing mean Cladocera body size in several lakes, mediated through the replacement of smaller-bodied with larger-bodied Cladocera. These trends were attributed to declining food (phytoplankton) availability related to declining TP concentrations, declining acidity, alterations to planktivory through the spread of predatory bass populations, and the introduction of the predatory cladoceran, Bythotrephes longima$n u s$, in some lakes.

Long-term monitoring datasets, such as those from the Muskoka-Haliburton region of Ontario, are powerful archives for evaluating changes in lake chemistry and biology that may result from multiple environmental stressors. However, even these valuable datasets do not extend to periods prior to the onset of major environmental disturbances. To extend existing records, paleolimnological techniques can be used to quantify environmental changes in lakes (Smol 2008). Moreover, analysing information preserved in lake sediments allows researchers to examine conditions in the preindustrial time period, thus providing baseline water quality conditions and information on biological assemblages. In this study, we use the 'top-bottom' paleolimnological approach, which allows us to compare environmental indicators preserved in the modern sediments (i.e. surface sediments) to those preserved in pre-industrial sediments (i.e. bottom sediments). Previously, top-bottom paleolimnological studies of this region have examined long-term changes in water quality using algal and invertebrate remains as environmental indicators (diatoms: Hall \& Smol 1996; chironomids: Quinlan et al.1998; chrysophyte cysts: Wilkinson et al. 1999; chrysophyte scales: Paterson et al. 2001, 2004). This paper extends these paleolimnological studies to Cladocera.

The order Cladocera (Crustacea: Branchiopoda) is a group of zooplankton that have considerable potential as paleolimnological indicators. They have been used in studies to infer environmental and community change over many spatial and temporal scales (Korhola \& Rautio 2001). Their skeletal structures are made of chitin, which is chemically inert and able to withstand varying degrees of degradation, depending on the species (Korhola \& Rautio 2001). Sedimentary cladoceran analysis can provide a link to higher trophic levels (e.g., fish) and also archive littoral taxa that are not easily captured in contemporary pelagic sampling procedures. The sediment deposited at the centre of a lake represents an integrated sample of both pelagic and littoral species (Frey 1988). Despite their potential as paleolimnological indicators, to the best of our knowledge, only four other top-bottom paleolimnological studies on Cladocera species assemblages have ever been published in the peer-reviewed literature. Taylor et al. (2006) found an increase in the relative abundance of pelagic and a decrease in benthic cladoceran species over time in five of six Irish lakes that have been subjected to anthropogenic nutrient enrichment throughout their histories. Suchy \& Hann (2007) examined top-bottom sediment cores from 16 sites in Lake of the Woods, Canada, to document the bosminid community assemblage prior to and following the introduction of Eubosmina coregoni. In a top-bottom study of 50 lakes from the central Canadian Arctic treeline region, Sweetman et al. (2008) found that shifts in cladoceran communities over time were slight in comparison to the increases in planktonic diatom populations, indicating a decoupling between the two trophic levels in their response to recent warming. Finally, using the same samples as the present study, Korosi et al. (2010) examined the changes in daphniid and bosminid size structure over time in south-central Ontario lakes and found that decreases in bosminid mucrone and antennule lengths reflected shifts in zooplankton community structure, including reduced copepod predation, while decreases in daphniid size were most plausibly linked to acidification and recovery.

Here, we present the top-bottom paleolimnological record of subfossil Cladocera from 42 south-central Ontario lakes that have been impacted by multiple anthropogenic stressors. We investigate changes in cladoceran community assemblages since pre-industrial times by comparing cladoceran remains in surface and pre-1850s sediment from a subset of lakes in the Muskoka-Haliburton region of south-central Ontario (Fig. 1). The main objectives of this research were: 1) to provide a summary of the baseline (i.e. pre-industrial) cladoceran communities from these well-studied reference lakes in south-central Ontario; 2) to determine if the relative abundances of pelagic and littoral cladoceran species have changed significantly over time; and 3 ) to assess the modern environmental factors that best explain changes in the cladoceran assemblages since pre-industrial times. Specifically, we examine the relationships between changes in cladoceran assemblages of these lakes over time and five key environmental variables that were identified by DeSellas et al. (2008) as having a significant influence on the spatial distribution of surface-sediment (i.e. present-day) cladoceran communities in the study lakes. These variables are: calcium $(\mathrm{Ca}) ; \mathrm{pH}$; sulphate $\left(\mathrm{SO}_{4}\right)$; dissolved organic carbon (DOC); maximum lake depth; and changes in fish predatory regimes. We also discuss possible influences of other known environmental stressors on the observed changes in the cladoceran communities, including declines in total phosphorus concentrations and recent climate warming.

\section{METHODS}

The 44 study lakes were chosen from a subset of lakes in the Muskoka-Haliburton region of Ontario (Fig. 1, Tab. 1). This lake database is maintained at the Onta- 


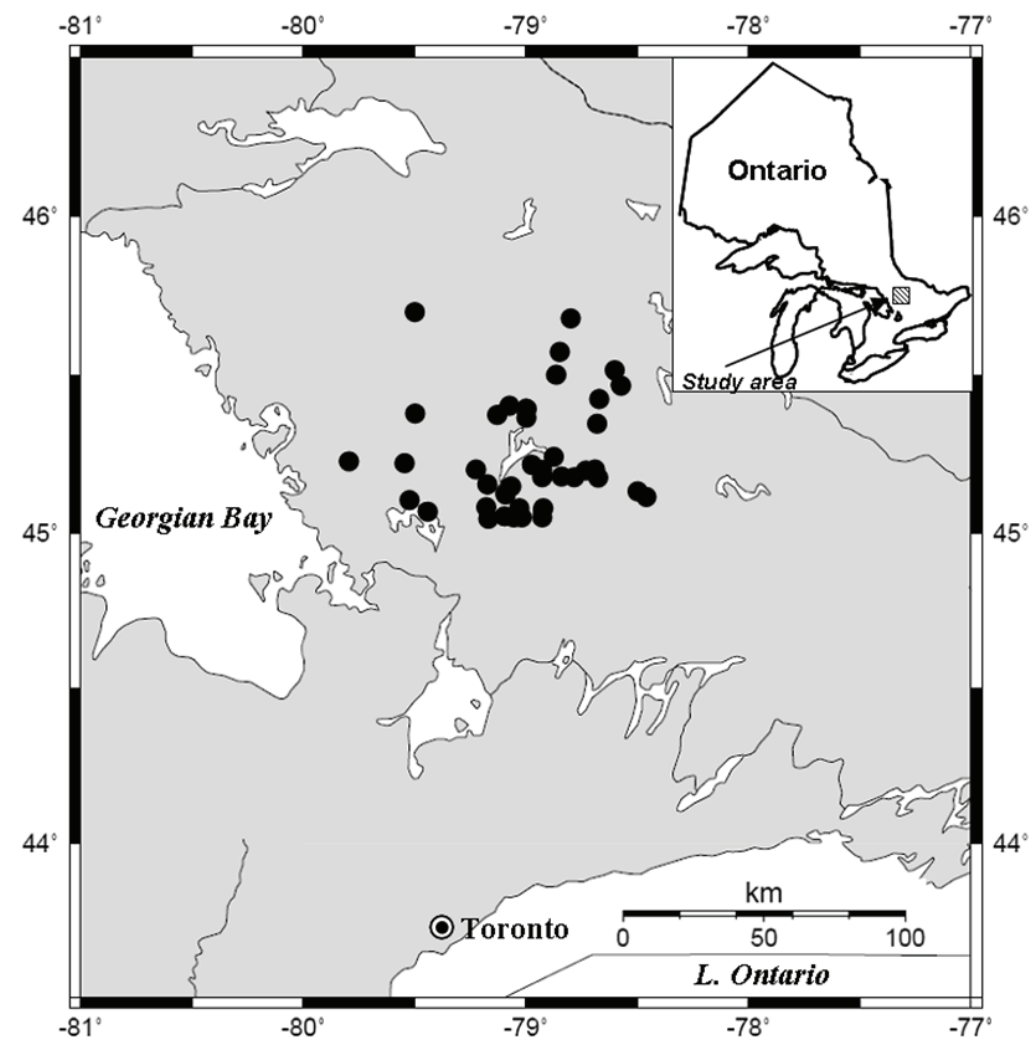

Fig. 1. Locations of the 44 study lakes in the Muskoka-Haliburton region of south-central Ontario, Canada.

rio Ministry of the Environment's (MOE) Dorset Environmental Science Centre (DESC). These study lakes were chosen to coincide with long-term zooplankton monitoring in this region, and reflect the range in acidity, nutrients and morphometry of south-central Ontario lakes on the Canadian Shield (Yan et al. 1996; Yan et al. 2008b). Located on the Precambrian Shield, the local bedrock is granitic and soils are generally acidic and nutrient-poor (Jeffries \& Snyder 1983). Although the region is currently characterized by mixed-deciduous and coniferous forests, extensive deforestation occurred in the mid- to late-1800s for agricultural purposes. Local agriculture was largely unsuccessful due to the rough topography, thin soils, and cool climate (Michalski et al. 1973). Most of the study lakes are surrounded by seasonal cottages and/or year-round residences, and are subjected to environmental stressors associated with recreational boating, fishing and tourism. Industrial pollution resulted in slightly elevated acid and metal deposition in the region throughout the 1970s (Dillon et al. 1978), although current rates of deposition of these industrial chemicals have declined appreciably (Yan et al. 2008a). Other potential stressors include invasive species introductions in some of the lakes (e.g., Bythotrephes longimanus, table 1; Boudreau \& Yan 2003; Drake et al. 2006), recent warming (e.g., Futter 2003), and declines in lakewater calcium and phosphorus levels (Stoddard et al. 1999; Watmough \& Dillon 2003).
Replicate cores for top (representing modern sediment) and bottom (representing pre-industrial sediment) analysis from the 44 lakes were collected in the autumns of 2004 and 2005. Sediment cores were collected from the deepest part of each lake using a Glew (1989) gravity corer or miniature Glew (1991) gravity corer. The cores were taken to shore and sampled using a Glew (1988) vertical extruder. The top $1 \mathrm{~cm}(0-1 \mathrm{~cm}$; representing modern lake conditions) of sediment and a $1 \mathrm{~cm}$ interval taken at a minimum core depth of 20-25 $\mathrm{cm}$ were obtained (representing pre-industrial lake conditions). Radiometric ${ }^{210} \mathrm{~Pb}$ sediment dating from other cores from lakes in this region, varying widely in surface area and morphometry, have repeatedly demonstrated that a sediment depth of 15 to $20 \mathrm{~cm}$ is representative of the pre-1850 period (e.g., Hall \& Smol 1996; Clerk et al. 2000; Little \& Smol 2001). The sediment was returned to the Paleoecological and Environmental Assessment and Research Laboratory (PEARL) at Queen's University in Kingston, Ontario, and stored at $4{ }^{\circ} \mathrm{C}$ until analyzed.

The top and bottom sediment samples were analyzed for cladoceran remains. Replicate microscope slides of each of the 44 lakes were prepared following the techniques detailed in Korhola \& Rautio (2001). Sediment was deflocculated in a $10 \%$ potassium hydroxide solution and heated at $80{ }^{\circ} \mathrm{C}$ for approximately 30 minutes. The sediment was then passed through at $37 \mu \mathrm{m}$ sieve and rinsed with de-ionized water until all small 
Tab. 1. Geographical location and relative abundances of the dominant cladoceran families from 44 study lakes in southcentral Ontario. Summary statistics [(minimum, maximum, mean, and standard deviation (SD)] represent all study lakes except those identified as outliers (Brandy and Glen lakes; in bold-italics). Asterisks (*) denote lakes that were invaded by Bythotrephes longimanus before the year of sampling.

\begin{tabular}{|c|c|c|c|c|c|c|c|c|c|c|}
\hline \multirow[b]{2}{*}{ Lake } & \multirow[b]{2}{*}{ Latitude $(\mathrm{N})$} & \multirow[b]{2}{*}{ Longitude (W) } & \multicolumn{2}{|c|}{ Daphniidae (\%) } & \multicolumn{2}{|c|}{ Bosminidae $(\%)$} & \multicolumn{2}{|c|}{ Chydoridae (\%) } & \multicolumn{2}{|c|}{ Pelagic:Littoral } \\
\hline & & & $2004-05$ & Pre-1850s & $2004-05$ & Pre-1850s & $2004-05$ & Pre-1850s & $2004-05$ & Pre-1850s \\
\hline Axe & $45^{\circ} 23^{\prime}$ & $79^{\circ} 30^{\prime}$ & 9.6 & 0.0 & 49.6 & 51.0 & 35.2 & 48.2 & 3.8 & 2.5 \\
\hline Basshaunt & $45^{\circ} 07^{\prime}$ & $78^{\circ} 28^{\prime}$ & 40.8 & 16.3 & 43.8 & 66.1 & 11.9 & 15.4 & 7.0 & 7.9 \\
\hline Bigwind & $45^{\circ} 03^{\prime}$ & $79^{\circ} 03^{\prime}$ & 26.6 & 14.7 & 48.6 & 58.9 & 14.7 & 10.5 & 4.2 & 3.2 \\
\hline Blue Chalk & $45^{\circ} 12^{\prime}$ & $78^{\circ} 56^{\prime}$ & 23.0 & 25.9 & 55.3 & 51.2 & 18.0 & 19.4 & 7.9 & 5.5 \\
\hline Bonnechere & $45^{\circ} 28^{\prime}$ & $78^{\circ} 35^{\prime}$ & 42.2 & 60.2 & 33.9 & 21.5 & 8.3 & 6.0 & 12.0 & 12.0 \\
\hline Brandy & $45^{\circ} 06^{\prime}$ & $79^{\circ} 31^{\prime}$ & 35.9 & 80.7 & 51.4 & 1.0 & 10.2 & 14.5 & 12.8 & 6.8 \\
\hline Buck & $45^{\circ} 23^{\prime}$ & $79^{\circ} 00^{\prime}$ & 53.3 & 7.2 & 22.9 & 74.7 & 4.8 & 13.9 & 14.0 & 5.1 \\
\hline Chub & $45^{\circ} 13^{\prime}$ & $78^{\circ} 59^{\prime}$ & 27.3 & 20.3 & 52.5 & 60.2 & 8.1 & 15.3 & 16.4 & 4.8 \\
\hline Cinder E. & $45^{\circ} 04^{\prime}$ & $78^{\circ} 56^{\prime}$ & 2.8 & 7.9 & 88.7 & 73.6 & 1.9 & 8.7 & 25.1 & 14.7 \\
\hline Cinder W. & $45^{\circ} 04^{\prime}$ & $78^{\circ} 56^{\prime}$ & 0.7 & 2.0 & 93.2 & 80.3 & 5.1 & 16.1 & 28.4 & 9.2 \\
\hline Cradle & $45^{\circ} 28^{\prime}$ & $78^{\circ} 35^{\prime}$ & 35.3 & 57.8 & 43.1 & 24.3 & 10.8 & 9.9 & 5.8 & 6.2 \\
\hline Crosson & $45^{\circ} 05^{\prime}$ & $79^{\circ} 02^{\prime}$ & 46.3 & 13.5 & 21.5 & 74.2 & 2.0 & 10.9 & 32.0 & 7.8 \\
\hline Crown & $45^{\circ} 26^{\prime}$ & $78^{\circ} 40^{\prime}$ & 35.4 & 63.7 & 53.4 & 15.7 & 8.3 & 10.8 & 13.2 & 5.4 \\
\hline Delano & $45^{\circ} 31^{\prime}$ & $78^{\circ} 36^{\prime}$ & 14.8 & 57.0 & 66.7 & 19.8 & 14.1 & 14.1 & 10.0 & 8.8 \\
\hline Devine* & $45^{\circ} 12^{\prime}$ & $79^{\circ} 14^{\prime}$ & 36.8 & 14.2 & 30.2 & 47.7 & 10.4 & 6.1 & 7.8 & 6.4 \\
\hline Dickie & $45^{\circ} 09^{\prime}$ & $79^{\circ} 05^{\prime}$ & 26.7 & 0.0 & 47.6 & 76.3 & 16.2 & 21.5 & 5.9 & 4.9 \\
\hline Glen & $45^{\circ} 08^{\prime}$ & $78^{\circ} 30^{\prime}$ & 59.0 & 4.2 & 27.9 & 66.4 & 11.6 & 27.9 & 8.7 & 3.3 \\
\hline Hamer & $45^{\circ} 14^{\prime}$ & $79^{\circ} 48^{\prime}$ & 8.9 & 0.0 & 55.3 & 51.3 & 16.3 & 21.9 & 7.0 & 3.5 \\
\hline Harp* & $45^{\circ} 23^{\prime}$ & $79^{\circ} 07^{\prime}$ & 1.4 & 0.0 & 77.5 & 91.6 & 20.8 & 7.9 & 4.4 & 23.1 \\
\hline Healey & $45^{\circ} 05^{\prime}$ & $79^{\circ} 11^{\prime}$ & 8.6 & 0.0 & 74.4 & 82.2 & 12.3 & 12.9 & 6.3 & 9.2 \\
\hline Heney & $45^{\circ} 08^{\prime}$ & $79^{\circ} 06^{\prime}$ & 0.0 & 0.0 & 49.5 & 74.3 & 42.4 & 21.2 & 1.3 & 5.0 \\
\hline Kimball* & $45^{\circ} 21^{\prime}$ & $78^{\circ} 41^{\prime}$ & 17.4 & 19.7 & 56.0 & 53.3 & 18.8 & 24.9 & 3.6 & 3.8 \\
\hline Leech & $45^{\circ} 03^{\prime}$ & $79^{\circ} 06^{\prime}$ & 35.8 & 0.0 & 33.8 & 80.7 & 26.3 & 18.5 & 2.7 & 5.4 \\
\hline Leonard* & $45^{\circ} 04^{\prime}$ & $79^{\circ} 27^{\prime}$ & 41.3 & 36.7 & 48.4 & 55.2 & 5.0 & 5.7 & 18.4 & 7.0 \\
\hline Little Clear & $45^{\circ} 24^{\prime}$ & $79^{\circ} 00^{\prime}$ & 22.2 & 15.2 & 43.5 & 58.5 & 30.2 & 25.5 & 3.0 & 24.4 \\
\hline Maggie & $45^{\circ} 30^{\prime}$ & $78^{\circ} 52^{\prime}$ & 2.4 & 0.9 & 86.5 & 88.5 & 10.1 & 10.1 & 16.6 & 9.7 \\
\hline McKay & $45^{\circ} 03^{\prime}$ & $79^{\circ} 10^{\prime}$ & 6.3 & 6.7 & 71.3 & 60.5 & 4.2 & 16.8 & 9.9 & 3.4 \\
\hline Moot & $45^{\circ} 09^{\prime}$ & $79^{\circ} 10^{\prime}$ & 2.1 & 0.0 & 73.0 & 67.0 & 21.6 & 29.3 & 5.3 & 3.3 \\
\hline Nunikani* & $45^{\circ} 12^{\prime}$ & $78^{\circ} 44^{\prime}$ & 20.1 & 1.0 & 63.8 & 88.1 & 12.2 & 10.9 & 9.3 & 22.5 \\
\hline Pearceley & $45^{\circ} 42^{\prime}$ & $79^{\circ} 30^{\prime}$ & 3.2 & 0.0 & 73.6 & 73.8 & 22.3 & 24.8 & 4.0 & 4.0 \\
\hline Pincher & $45^{\circ} 34^{\prime}$ & $78^{\circ} 51^{\prime}$ & 11.1 & 20.6 & 68.4 & 56.3 & 17.9 & 21.4 & 5.9 & 4.8 \\
\hline Plastic & $45^{\circ} 11^{\prime}$ & $78^{\circ} 50^{\prime}$ & 12.0 & 20.0 & 80.3 & 70.0 & 6.0 & 5.8 & 16.6 & 14.9 \\
\hline Poker E. & $45^{\circ} 03^{\prime}$ & $78^{\circ} 56^{\prime}$ & 0.0 & 16.3 & 90.1 & 72.1 & 8.3 & 7.7 & 12.1 & 11.2 \\
\hline Poker W. & $45^{\circ} 03^{\prime}$ & $78^{\circ} 56^{\prime}$ & 1.4 & 12.3 & 82.0 & 69.3 & 13.8 & 11.2 & 8.1 & 9.2 \\
\hline Red Chalk E. & $45^{\circ} 11^{\prime}$ & $78^{\circ} 56^{\prime}$ & 8.1 & 8.2 & 68.8 & 58.8 & 16.6 & 32.2 & 5.0 & 3.3 \\
\hline Red Chalk M. & $45^{\circ} 11^{\prime}$ & $78^{\circ} 56^{\prime}$ & 30.1 & 21.3 & 45.1 & 58.7 & 17.3 & 18.7 & 4.1 & 6.2 \\
\hline Red Pine* & $45^{\circ} 12^{\prime}$ & $78^{\circ} 42^{\prime}$ & 28.6 & 3.8 & 62.3 & 85.1 & 8.2 & 10.6 & 15.4 & 10.5 \\
\hline Saw & $45^{\circ} 03^{\prime}$ & $79^{\circ} 02^{\prime}$ & 27.9 & 0.0 & 42.4 & 73.4 & 14.5 & 21.8 & 8.1 & 5.5 \\
\hline Sherborne* & $45^{\circ} 11^{\prime}$ & $78^{\circ} 47^{\prime}$ & 27.4 & 49.0 & 61.1 & 39.3 & 5.8 & 7.1 & 11.3 & 9.2 \\
\hline Smoke & $45^{\circ} 31^{\prime}$ & $78^{\circ} 41^{\prime}$ & 6.1 & 11.5 & 86.1 & 79.2 & 7.8 & 5.2 & 17.7 & 12.4 \\
\hline Solitaire & $45^{\circ} 22^{\prime}$ & $79^{\circ} 00^{\prime}$ & 33.1 & 33.2 & 56.0 & 40.9 & 6.6 & 11.3 & 13.6 & 4.1 \\
\hline Timberwolf & $45^{\circ} 41^{\prime}$ & $78^{\circ} 48^{\prime}$ & 17.6 & 31.2 & 68.7 & 60.1 & 9.7 & 7.1 & 9.5 & 16.5 \\
\hline Walker & $45^{\circ} 24^{\prime}$ & $79^{\circ} 05^{\prime}$ & 51.4 & 46.0 & 34.3 & 40.3 & 6.2 & 10.8 & 22.8 & 10.6 \\
\hline Young* & $45^{\circ} 13^{\prime}$ & $79^{\circ} 33^{\prime}$ & 15.2 & 6.6 & 72.1 & 79.9 & 5.8 & 8.4 & 11.0 & 17.6 \\
\hline Min. & & & 0.0 & 0.0 & 21.5 & 15.7 & 1.9 & 5.2 & 1.3 & 2.5 \\
\hline Max. & & & 59.0 & 80.7 & 93.2 & 91.6 & 42.4 & 32.2 & 32.0 & 24.4 \\
\hline Mean & & & 20.5 & 17.2 & 58.9 & 62.0 & 13.2 & 15.2 & 10.6 & 8.7 \\
\hline $\mathrm{SD}$ & & & 15.6 & 18.8 & 18.8 & 19.1 & 8.7 & 8.7 & 7.1 & 5.6 \\
\hline
\end{tabular}

particulate matter had washed through. Residue that was retained on the sieve was transferred to a small vial using de-ionized water. Subsequently, two to three drops of ethanol and safranin-glycerin solution were added to prevent fungal growth and stain the cladoceran remains, respectively. Slides were prepared by pipetting $50 \mu \mathrm{L}$ aliquots onto glass slides and affixing the cover slips with glycerine jelly stained with safranin.

Taxonomic identifications of fossil cladocerans (daphniids, bosminids, and chydorids) followed several sources, including Bos (2001), Chengalath \& Hann (1981a, b), De Melo \& Hebert (1994), Flössner \& Kraus (1977), Frey $(1959,1962,1965,1980,1985,1987)$, Hann (1982), Hebert (1995), Korovchinsky (1992), Megard (1967), Pennak (1989), Smirnov (1974, 1996), and Taylor, Ishikane \& Haney (2002). A minimum of 100 cladocerans were enumerated using a Leica DMRB light microscope with brightfield optics (10-40X objective, 15X ocular lens). Kurek et al. (2010) recently demonstrated that a sum of 100 cladoceran remains is an adequate sum for most paleolimnological assessments. All cladoceran remains (e.g., carapaces, head 
shields, ephippia, and postabdominal claws) were tabulated separately. For each taxon, the most abundant remain was used to calculate the number of individuals (Frey 1986). Usually 2-3 slides were sufficient to enumerate 100 animals. Daphnia species were placed into one of two groupings based on the morphology of the middle pectin on the postabdominal claw (Colbourne \& Hebert 1996), including the Daphnia pulex complex (stout middle pectin) or the D. longispina complex (uniform middle pectin). Bosminid remains were separated into one of two groupings (Bosmina spp. or Eubosmina spp.) based on the morphology of the lateral headpore on the head shield (Taylor et al. 2002).

The water chemistry data used in our analyses were collected during the ice-free seasons of 2004 and 2005 (MOE, DESC, unpublished data; M. Palmer, York University, Toronto, ON, personal communication). In a previous study, DeSellas et al. (2008) found that cladoceran remains preserved in the surface sediments of these lakes were significantly related to five environmental variables: sulphate, calcium, dissolved organic carbon, $\mathrm{pH}$, and maximum lake depth $\left(\mathrm{Z}_{\max }\right)$.

At the time of sediment coring (2004-'05), the invasive cladoceran Bythotrephes longimanus had invaded eight lakes in the data set, including Devine, Harp, Kimball, Leonard, Nunikani, Red Pine, Sherborne, and Young lakes (Palmer \& Yan, York University, unpublished data).

\subsection{Statistical Analysis}

Two lakes (Glen and Brandy lakes) were found to be outliers based on PCA axes scores (sensu Hall \& Smol 1996). Specifically, Glen Lake (catchment located on a marble intrusion) has high conductivity, dissolved inorganic carbon (DIC), alkalinity, sulphate and calcium concentrations. Furthermore, Brandy Lake is highly coloured with elevated phosphorus, alkalinity, sulphate and $\mathrm{Ca}$ concentrations. These lakes were removed from further statistical analysis [see DeSellas et al. (2008) for details of outlier screening procedures]. The cladoceran data from the remaining $(\mathrm{n}=42)$ modern and pre-industrial sediment samples were pre-screened prior to statistical analyses to reduce the influence of rare taxa. Relative abundances were calculated by expressing the number of individuals of a species as a percentage of the total number of Cladocera for that lake. Cladoceran taxa that were not present in at least two lakes with a relative abundance of $\geq 2 \%$ or more in one sample were removed from statistical analyses. Community similarities were calculated using the Bray-Curtis similarity coefficient (Bray \& Curtis 1957) on square root-transformed species data, and used to construct a similarity matrix among modern and pre-industrial sediment samples. Using this matrix, an analysis of similarities (ANOSIM) was calculated to test for significant differences in cladoceran assemblage composition between modern and pre-industrial sediment samples, using the Ply- mouth Routines in Multivariate Ecological Research (PRIMER) statistical software package (version 5, Clarke \& Warwick 1994). ANOSIM is a nonparametric test analogous to a multivariate one-factor ANOVA (Clarke \& Green 1988; Clarke \& Warwick 1994) where within- and across-group rank dissimilarities were computed, shuffled, recalculated repeatedly (10,000 times) between sample pairs and compared with the original rank dissimilarities to calculate a significance $(p)$ value. For each analysis, ANOSIM produced a global $R$ value between 0 (minimal separation between groups) and 1 (maximal separation between groups) (Clarke \& Warwick 1994). The cladoceran taxa primarily responsible for the observed differences in assemblage composition between sampling periods were identified using the statistical procedure similarity percentages (SIMPER, Clarke 1993) in PRIMER (Clarke \& Warwick 2001).

Each Cladocera taxon was grouped according to its preferred habitat (i.e. pelagic or littoral), following Paterson (1994), recognizing that few zooplankton species are limited exclusively to the pelagic region (Walseng et al. 2006). To test the null hypothesis of no significant increases in the ratio of the relative abundance of pelagic to littoral cladoceran species since pre-industrial times, we used a non-parametric Wilcoxon signed-rank test (Sokal \& Rohlf 1981). The percent change in the relative abundances of three cladoceran groups (bosminids, daphniids, and chydorids) was calculated by subtracting the relative abundance of the pre-industrial sediment from the relative abundance of the modern sediments. These values were then examined in relation to a subset of environmental variables found previously (DeSellas et al. 2008) to be significant in structuring the modern cladoceran assemblages (calcium, $\mathrm{pH}$, dissolved organic carbon, sulphate, maximum lake depth). Each environmental variable was divided $a$ priori into five category groupings. Boxplots were then used to examine changes in daphniid and bosminid relative abundances over time in relation to these category groupings of environmental variables, and KruskalWallis ANOVA on ranks were used to test whether the changes in relative abundances among groupings were significantly different.

In addition to the environmental variables discussed above, we tested the importance of hydrological management on changes in zooplankton assemblages. The degree of hydrological management may affect lake depth and hence the size of the pelagic zone in lakes, resulting in changes in the pelagic and littoral cladoceran communities (Hoffman 1998). Each lake was classified according to its level of hydrological management (sensu Quinlan \& Smol 2002; R. Girard, MOE, DESC, unpublished data), and subsequently examined in relation to the percentage of change between modern and pre-industrial pelagic and littoral taxa (pelagic:littoral ratio). Similarly, to determine if the amount of change in the pelagic:littoral ratio over time could be 
attributed to certain environmental conditions, five separate simple linear regressions were performed using the explanatory variables $\left(\mathrm{Ca}, \mathrm{pH}, \mathrm{SO}_{4}, \mathrm{DOC}, \mathrm{Z}_{\max }\right)$, and the dependent variable (pelagic:littoral ratio).

Fish are important regulators of zooplankton communities through predation (Findlay et al. 2007). Predatory bass are spreading across this region (Kerr 2006), and the introduction of bass may cause a dramatic reduction in the abundances of planktivorous fish, resulting in a population increase in large Cladocera, particularly daphniids (MacRae \& Jackson 2001; Vander Zanden et al. 2004). To investigate the relationship between zooplankton relative abundance and fish community metrics, fish community relative biomass data for a subset of 24 lakes in the dataset were obtained from Dr. J. Gunn and G. Morgan (unpublished data, Laurentian University, Sudbury, Ontario, Canada). Fish community relative biomass is the average grams of fish per net, which is often used when comparing fish composition among lakes (G. Morgan, Biology Department, Laurentian University, Sudbury, Ontario, personal communication).

\section{RESULTS}

Cladoceran remains were well-preserved and abundant in both the modern and pre-industrial sediment samples of the 42 study lakes. Following the pre-screening techniques noted above, the top-bottom sediment assemblages were represented by 16 cladoceran taxa (Tab. 2). The cladoceran assemblages recorded in the modern and pre-industrial sediment samples were significantly different (ANOSIM, $R=0.09, p=0.02, \mathrm{n}=42$; Clarke \& Green 1988).

Tab. 2. List of 16 cladoceran taxa that had relative abundances of at least $2 \%$ in at least 2 or more study lakes.

\begin{tabular}{lll}
\hline Family & Species & Habitat \\
\hline Bosminidae & Bosmina spp. & Pelagic \\
Bosminidae & Eubosmina spp. & Pelagic \\
Daphniidae & Daphnia longispina complex & Pelagic \\
Daphniidae & Daphnia pulex complex & Pelagic \\
Holopedidae & Holopedium sp. & Pelagic \\
Chydoridae & Acroperus harpae & Littoral \\
Chydoridae & Alona excisa & Littoral \\
Chydoridae & Alona intermedia & Littoral \\
Chydoridae & Alona quadrangularis & Littoral \\
Chydoridae & Alona rustica & Littoral \\
Chydoridae & Alonella nana & Littoral \\
Chydoridae & Chydorus bicornutus & Littoral \\
Chydoridae & Chydorus brevilabris & Littoral \\
Chydoridae & Chydorus piger & Littoral \\
Chydoridae & Disparalona leei & Littoral \\
Sididae & Sida spp., Diaphanosoma spp. & Littoral \\
\hline
\end{tabular}

Furthermore, examination of the relative abundances of each taxon showed clear differences between top and bottom sedimentary cladoceran assemblages (Tab. 1; Fig. 2). Remains of the bosminid cladoceran group were the most frequently enumerated taxa in both the top and bottom samples. In 20 of the 42 study lakes, bosminids increased in relative abundance since pre-industrial times, with 14 of the 42 study lakes demonstrating an increase of more than $10 \%$ (Tab. 1). The most abundant cladoceran taxon in the modern samples was Bosmina spp., occurring at an average relative abundance of $48 \%$ ( $\mathrm{SD} \pm 23 \%$ ) across the 42 lakes, and reaching relative abundances of greater than $50 \%$ in 19 of 42 lakes. Eubosmina spp. also contributed to high bosminid totals, with an average relative abundance of $10 \%(\mathrm{SD} \pm$ $9 \%$ in modern sediment samples. The relative abundance of bosminids was generally higher in preindustrial sediment (Tab. 1), occurring at an average of $62 \%(\mathrm{SD} \pm 19 \%)$ in 42 of the study lakes. Bosmina spp. was also the most abundant cladoceran taxon in preindustrial time-periods and was found at a mean relative abundance of $54 \%(\mathrm{SD} \pm 23 \%)$ in fossil samples.

Daphniids increased in relative abundance since preindustrial times in 23 of the 42 lakes examined (Fig. 2, Tab. 1), with 18 of the 42 study lakes demonstrating an increase of more than 5\% (Axe, Basshaunt, Bigwind, Buck, Chub, Crosson, Devine, Dickie, Hamer, Healey, Leech, Little Clear, Nunikani, Red Chalk M., Red Pine, Saw, Walker \& Young). Daphniid relative abundances exceeded $25 \%$ in 18 study lakes in the modern sediments, and occurred at an average of $21 \%$ ( $\mathrm{SD} \pm 16 \%$ ) (Tab. 1). Daphniids belonging to the D. pulex complex were most abundant in the modern sediment samples, occurring at an average relative abundance of $10 \%$ (SD $\pm 12 \%$ ). In addition, 12 of 42 lakes demonstrated a decline in daphniid relative abundance of more than 5\% since pre-industrial times (Bonnechere, Cinder E., Cradle, Crown, Delano, Pincher, Plastic, Poker E., Poker W., Sherborne, Smoke \& Timberwolf; Tab. 1). The D. pulex complex and $D$. longispina complex relative abundances were $5 \%(\mathrm{SD} \pm 11 \%)$ and $13 \%(\mathrm{SD} \pm 14 \%)$ in pre-industrial sediments, respectively. Although it was a small change overall, the average relative abundance of chydorids was significantly lower in the modern sediments (Wilcoxon signed-rank test, $p=0.03$ ), with an average of $13 \%$ ( $\mathrm{SD} \pm 9 \%$ ) compared to an average of $15 \%(\mathrm{SD} \pm 9 \%)$ in the pre-industrial sediment ( $\mathrm{Tab}$. $1)$.

The SIMPER Routine (Clarke 1993) identified Bosmina spp. and the Daphnia longispina complex to be the species most represented in both the modern and pre-industrial sediment samples. SIMPER analysis determined that the primary species responsible for differences in assemblages between the time periods were the Daphnia pulex complex, the D. longispina complex, Eubosmina spp., Bosmina spp., and Holopedium sp. (Tab. 3). Across all lakes, the D. pulex complex, Eubosmina spp., and Holopedium sp. increased over time while the D. longispina complex and Bosmina spp. declined slightly in relative abundance over time (Fig. 2, Tab. 3). 


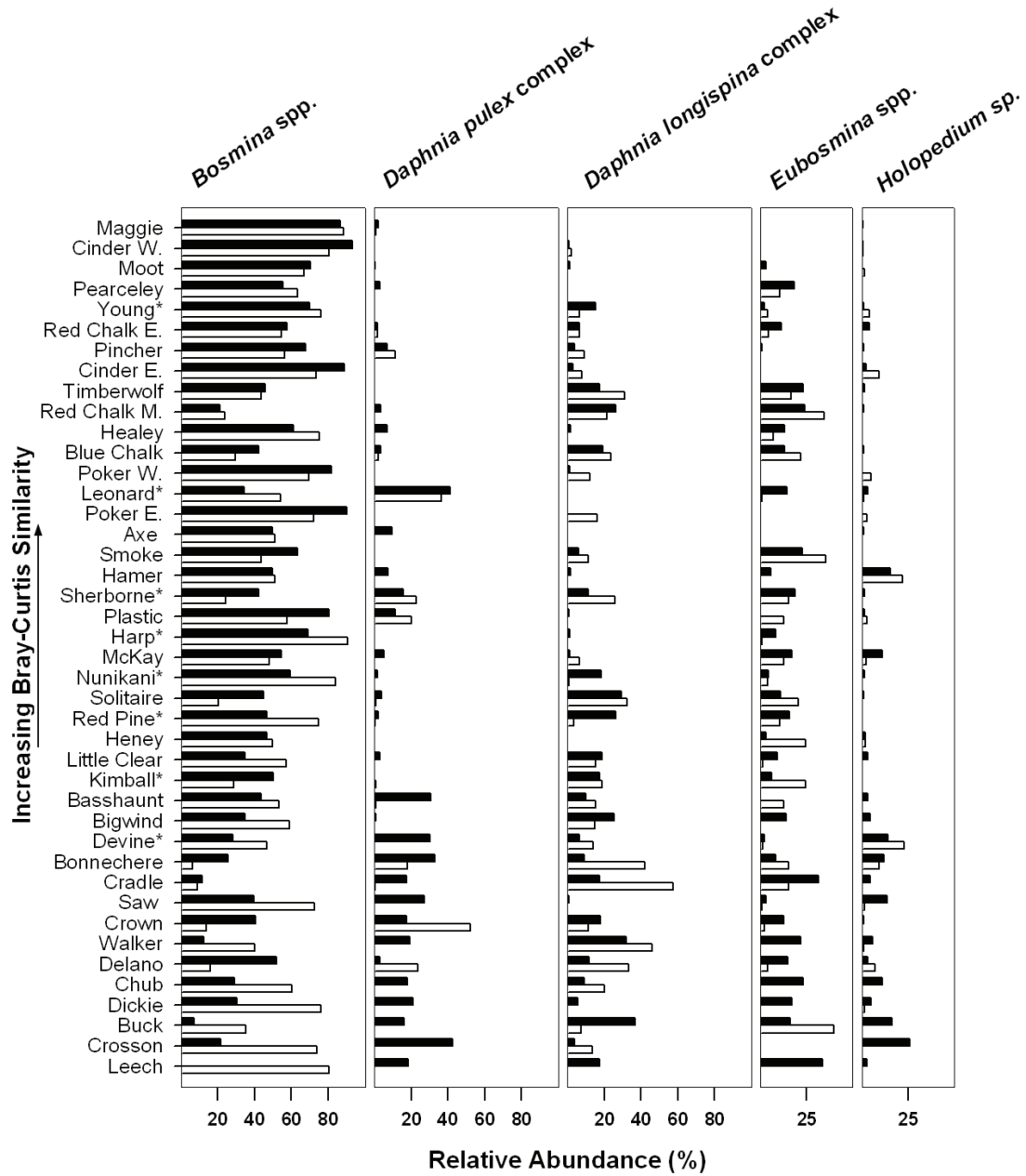

Fig. 2. Comparison between the relative percent abundances of the five most common (from Tab. 2) cladoceran taxa in modern and pre-industrial sediments for the 42 study lakes in south-central Ontario. Modern and pre-industrial cladoceran relative abundances are represented by solid bars and open bars, respectively. The lakes are organized in order of decreasing Bray-Curtis Similarity between top and bottom cladoceran assemblages. Asterisks $\left(^{*}\right)$ denote lakes that were invaded by Bythotrephes longimanus before the time of sampling (Yan \& Palmer unpublished data). Relative abundances were calculated using the entire cladoceran dataset.

Tab. 3. Results of a SIMPER test identifying the proportion that each cladoceran taxon contributed to the differences between modern (top) and pre-industrial (bottom) sediment samples (indicated by \% Contribution). These data show that the five primary species responsible for differences in assemblages between the time periods were the Daphnia pulex complex, the D. longispina complex, Eubosmina spp., Bosmina spp., and Holopedium gibberum.

\begin{tabular}{lcccc}
\hline & \multicolumn{2}{c}{ Relative Abundance (\%) } & \multirow{2}{*}{ Contribution (\%) } & $\begin{array}{c}\text { Cumulative } \\
\text { contribution (\%) }\end{array}$ \\
\cline { 2 - 3 } & Present-day & Pre-industrial & & 13.86 \\
Daphnia pulex complex & 11.54 & 6.13 & 12.08 & 13.86 \\
Daphnia longispina complex & 10.19 & 12.18 & 11.81 & 37.94 \\
Eubosmina sp. & 10.01 & 7.97 & 11.19 & 48.94 \\
Bosmina sp. & 48.05 & 52.74 & 7.67 & 56.61 \\
Holopedium gibberum & 4.03 & 2.22 & 5.16 & 61.77 \\
Alonella nana & 1.60 & 2.14 & 4.70 & 66.46 \\
Sididae & 2.01 & 2.54 & 4.29 & 70.76 \\
Alona intermedia & 1.16 & 1.10 & 3.91 & 74.67 \\
Alona excisa & 0.81 & 1.46 & 3.87 & 78.54 \\
Chydorus piger & 1.14 & 0.87 & 3.79 & 82.33 \\
Chydorus brevilabris & 1.10 & 0.64 & 3.74 & 86.07 \\
Chydorus bicornutus & 0.78 & 0.82 & 3.62 & 89.69 \\
Disparalona leei & 0.49 & 0.92 & 3.60 & 93.28 \\
Alona quadrangularis & 0.83 & 0.75 & 3.50 & 96.79 \\
Alona rustica & 0.80 & 0.69 & 3.21 & 100.00 \\
Acroperus harpae & 0.59 & 0.65 & &
\end{tabular}




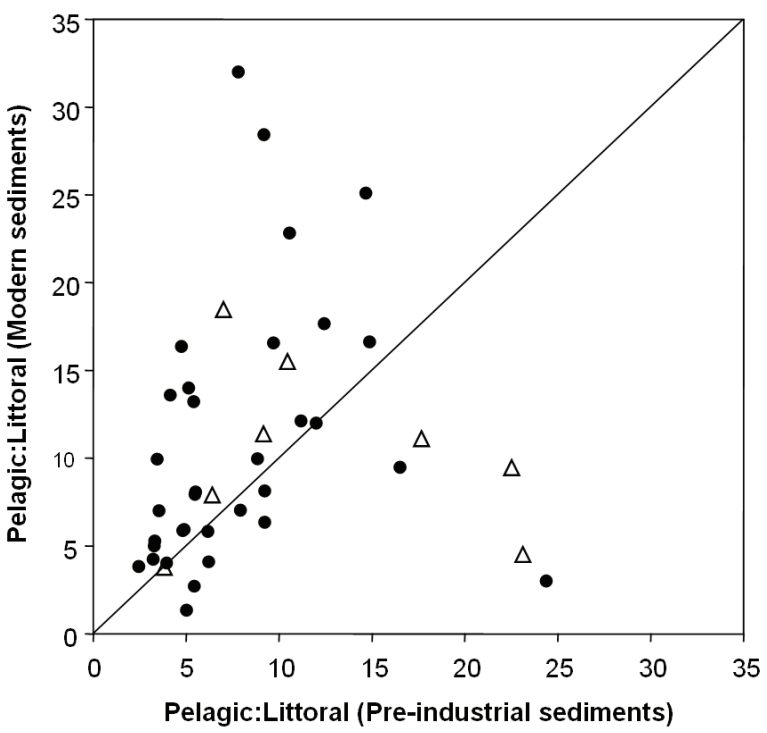

Fig. 3. The relationship between the ratios of pelagic to littoral fossil cladoceran taxa in modern and pre-industrial sediment samples from 42 lakes in south-central Ontario. The diagonal line represents the one to one line. Triangle symbols denote lakes that contained Bythotrephes longimanus before the time of sampling. The majority of lakes lie above the one to one line, indicating higher relative abundances of pelagic cladoceran species in modern (surface) sediments.

A comparison of the modern and pre-industrial sediment intervals suggested that there has been a significant increase in the pelagic to littoral (pelagic:littoral) cladoceran ratio since pre-industrial times (Wilcoxon signed-rank test, $p=0.02$; Fig. 3). The degree of hydrological management did not significantly explain this increase in the pelagic:littoral ratio (Fig. 4, KruskalWallis ANOVA on ranks, $\mathrm{H}=5.97, p=0.20, \mathrm{df}=4$ ), nor did any of the other environmental variables examined (Ca: $R^{2}=0.00, F=0.13, p=0.72 ; \mathrm{pH}: R^{2}=$ $0.01, F=0.59, p=0.45 ; \mathrm{SO}_{4}: R^{2}=0.00, F=0.16, p=$ $0.69 ; Z_{\max }: R^{2}=0.00, F=0.06, p=0.81$; DOC: $R^{2}=$ $0.01, F=0.53, p=0.47$ ).

Among the environmental variables tested $(\mathrm{Ca}, \mathrm{pH}$, DOC, $\mathrm{SO}_{4}, \mathrm{Z}_{\max }$ ), only $\mathrm{Ca}$ was found to be significantly related to changes in top and bottom cladoceran relative abundances (Fig. 5). When lakes were separated into five categories based on $\mathrm{Ca}$ concentrations, there were statistically significant differences in changes in the relative abundances of daphiniids (Kruskal-Wallis ANOVA on ranks, $p=0.01$, figure $5 \mathrm{a}$, table 4 ) and bosminids (Kruskal-Wallis ANOVA on ranks, $p=0.03$, figure $5 \mathrm{~b}$, table 4 ) among categories. Conversely, lakes higher in $\mathrm{Ca}\left(>2.0 \mathrm{mg} \mathrm{Ca} \mathrm{L}^{-1}\right)$ demonstrated a trend of decreased bosminid relative abundances and increased daphniid relative abundances over time (Figs 5a, b). Bosminid relative abundances demonstrated a trend nearly opposite to that of daphniids - an increase in relative abundance in lakes with $<2.0 \mathrm{mg} \mathrm{L}^{-1} \mathrm{Ca}$ and a decline in relative abundance in lakes with $\mathrm{Ca}$ concentrations between $2-3 \mathrm{mg} \mathrm{L}^{-1}$. However, despite the covariance of $\mathrm{pH}$ and $\mathrm{Ca}$ in this dataset $(r=0.80, p$ $\leq 0.01$; DeSellas et al. 2008), there was no relationship between changes in daphniid and bosminid relative abundances and category groupings of $\mathrm{pH}$ (Figs $5 \mathrm{~b}, \mathrm{c})$.

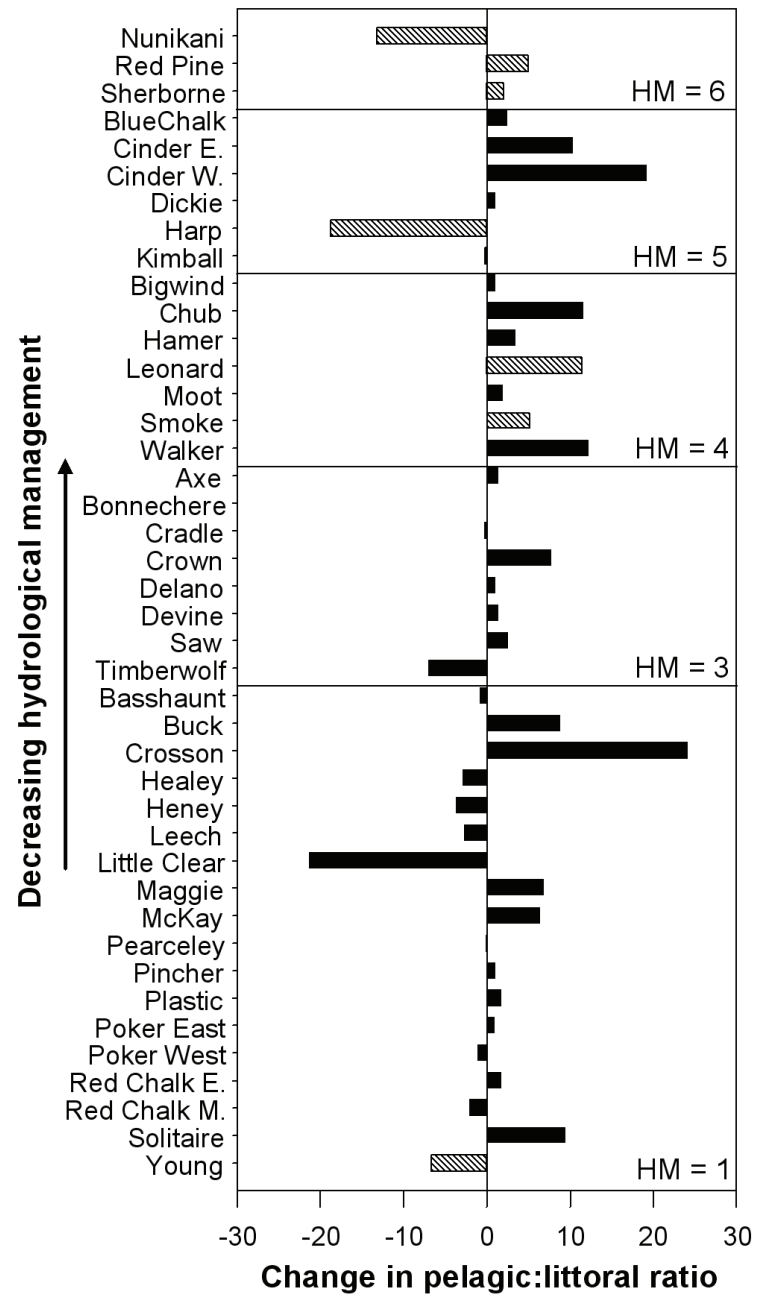

Fig. 4. Change in the pelagic to littoral ratio over time in relation to each lake's hydrological management (HM) classification: $1=$ dam at outlet; $3=$ dam at supply upstream lake chain; $4=$ culvert at outlet; $5=$ open channel outlet in lake chain affected by a dam a number of lakes downstream; $6=$ lake level with natural hydrology (sensu Quinlan \& Smol 2002; R. Girard, MOE, DESC, unpublished data). Hatched bars denote lakes that contained Bythotrephes longimanus before the time of sampling.

Similarly, there were no statistically significant differences in the changes in relative abundances of daphniids or bosminids for the remaining three environmental variables, $\mathrm{DOC}, \mathrm{SO}_{4}$, and $\mathrm{Z}_{\max }$, when the lakes were separated into categories of concentration and depth (Kruskal-Wallis ANOVA on ranks, $p>0.05$, figures $5 \mathrm{e}, \mathrm{j}$; Tab. 4). Although the changes in relative abundances of daphniids and bosminids with respect to DOC concentration were also not statistically significant ( $p>0.05$, figures $5 \mathrm{e}, \mathrm{f}$; Tab. 4 ), there appears to be a 

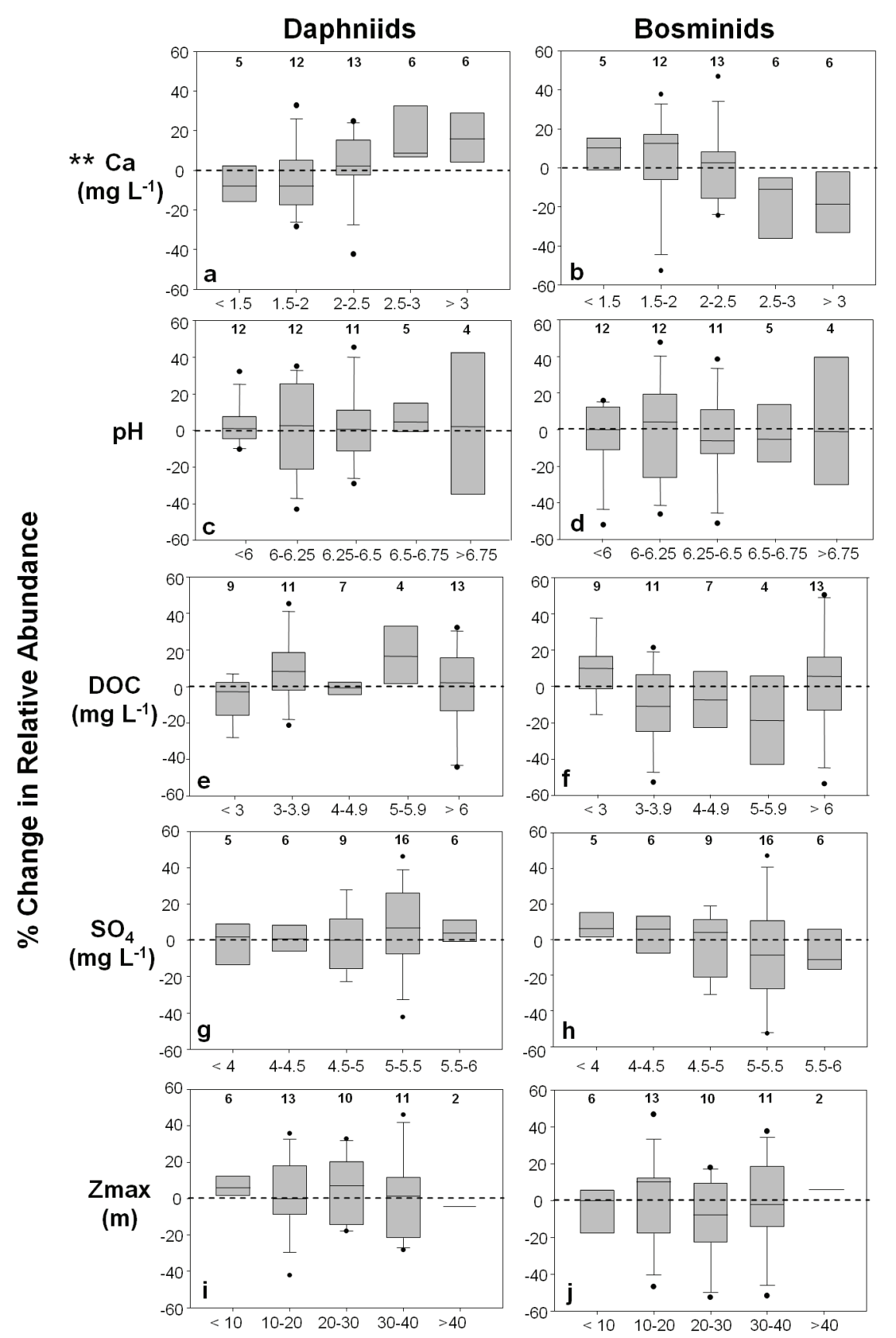

Fig. 5. Comparison of changes in the relative abundances of daphniid and bosminid subfossil remains since pre-industrial times for 42 south-central Ontario study lakes in relation to groupings of lakes according to calcium $(\mathrm{Ca})$, $\mathrm{pH}$, dissolved organic carbon (DOC), sulphate $\left(\mathrm{SO}_{4}\right)$, and maximum depth $\left(\mathrm{Z}_{\max }\right)$. Asterisks $(* *)$ denote statistically significant $(P \leq 0.05)$ differences between groupings of lakes for calcium based on Kruskal-Wallis ANOVAs on ranks (see Tab. 4 for detailed results). Lake sample sizes for each grouping are indicated above each category.

trend at the lower and higher ends of the DOC scale where daphniids declined over time in lakes with less than $3 \mathrm{mg} \mathrm{L}^{-1}$ DOC, but increased in lakes with $>7 \mathrm{mg}$ $\mathrm{L}^{-1}$ DOC.

In general, for a subset of 24 lakes with available fish data, lakes with low fish community biomass (500$1000 \mathrm{~g}_{\text {fish net }}{ }^{-1}$ ) showed a general increase in daphniid relative abundance since pre-industrial times while lakes with high fish relative biomass $\left(>2000 \mathrm{~g} \mathrm{net}^{-1}\right)$ showed no apparent change in daphniid relative abundance since pre-industrial times (Fig. 6). Despite these patterns, there was no significant relationship between changes in daphniid relative abundances and category groupings of fish community relative biomass for the subset of lakes (Kruskal-Wallis ANOVA on ranks, $p>0.05$, figure 6). 
Tab. 4. Results of Kruskal-Wallis ANOVA on ranks from comparisons of changes in relative abundances of daphniids and bosminids based on groupings of lakes according to the five environmental variables most important in influencing cladoceran community composition: calcium $(\mathrm{Ca}), \mathrm{pH}$, dissolved organic carbon (DOC), sulphate $\left(\mathrm{SO}_{4}\right)$, and maximum depth $\left(\mathrm{Z}_{\max }\right)$ (refer to Fig. 5). Asterisks (**) denote the only variable (Ca) whose median values among the various groupings was greater than would be expected by chance, thus indicating a statistically significant difference $(P \leq 0.05)$.

\begin{tabular}{lccccccc}
\hline & \multicolumn{3}{c}{$\%$ change in daphniids } & & \multicolumn{3}{c}{$\%$ change in bosminids } \\
\cline { 2 - 3 } \cline { 6 - 8 } & $\mathrm{H}$ & $\mathrm{df}$ & $\mathrm{P}$ & & $\mathrm{H}$ & $\mathrm{df}$ & $\mathrm{P}$ \\
\hline **Ca & 13.27 & 4 & 0.01 & & 10.90 & 4 & 0.03 \\
$\mathrm{DOC}$ & 5.75 & 4 & 0.22 & & 7.49 & 4 & 0.11 \\
pH & 0.28 & 4 & 0.99 & & 0.11 & 4 & 0.99 \\
$\mathrm{SO} 4$ & 2.05 & 4 & 0.73 & & 3.70 & 4 & 0.45 \\
$\mathrm{Z}_{\max }$ & 1.61 & 3 & 0.66 & & 2.17 & 3 & 0.54 \\
\hline
\end{tabular}

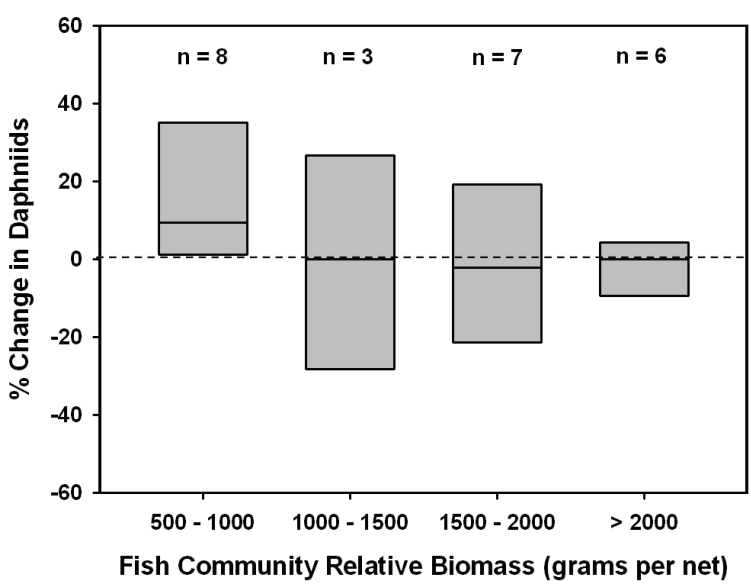

Fig. 6. Comparison of changes in the relative abundances of daphniid subfossil remains since pre-industrial times in relation to groupings of a subset of 24 south-central Ontario study lakes in relation to fish community relative biomass. These differences between groupings were not statistically significant based on a Kruskal-Wallis ANOVA on ranks $(P$ $>0.05)$. Lake sample sizes for each grouping are indicated above each category.

\section{DISCUSSION}

The 42 south-central Ontario study lakes have experienced two important shifts in the cladoceran communities since pre-industrial times. These include an overall increase in the ratio of pelagic to littoral communities in 30 of the 42 study lakes, and shifts within the pelagic communities to higher relative abundances of daphniids in 23 lakes. This region of Ontario has been subjected to multiple environmental stressors over the past few decades, including climate warming, increased DOC, $\mathrm{Ca}$ decline, changes in fish predation, and shifts in food availability (as measured by declines in phytoplankton standing stock that are coincident with declines in TP concentrations) (Yan et al. 2008a and references therein). Furthermore, water quality reconstructions from diatom assemblages suggest that many lakes in this region have declined in TP since pre-industrial times, and have both increased and decreased in $\mathrm{pH}$ over time (Hall \& Smol 1996). The observed changes in the cladoceran communities of these study lakes are likely the result of the interactions among these multiple environmental stressors. As previous studies have shown, the cumulative effects of multiple environmental stressors may be more influential than their individual parts (Christensen et al. 2006; Smol 2010), which makes the interpretation of these changes particularly challenging. Recognizing the limitations of not having direct historical data (and hence the paleolimnological approach), we discuss a number of potential drivers of cladoceran community changes over time, namely alterations in lake and soil geochemistry ( $\mathrm{Ca}$ and $\mathrm{DOC}$ ), biological factors (increases in piscivorous bass populations, declining food availability), and climate change.

The first major change since pre-industrial times is an overall shift in the ratio of pelagic to littoral cladocerans in 30 of 42 study lakes. Although we understand the limitations of using ratios to assess ecological changes over time, we discuss this change because, at a minimum, it suggests that pelagic Cladocera were relatively more successful in most lakes over recent years than in pre-industrial times. Recent increases in DOC concentrations in south-central Ontario lakes may have contributed to the shifts in the pelagic and littoral cladoceran communities. Long-term DOC concentrations have been increasing in a subset of south-central Ontario lakes over the past three decades (Monteith et al. 2006; Keller et al. 2008; Zhang et al. 2010). The resulting reductions in lake water clarity may have led to a decline in littoral macrophytes, which are often the preferred habitat of littoral species and also offer refuge from fish predation (e.g., Stansfield et al. 1997). However, Secchi transparency observations from eight intensively studied lakes in this region over the past three decades show little evidence of declining water clarity over time, either seasonally or annually (MOE, DESC, unpublished data). In contrast, water clarity in one lake (Plastic Lake, south-central Ontario) has increased between 1976-2007 for reasons unrelated to changes in DOC (MOE, DESC, unpublished data). Therefore, it is unlikely that DOC changes are the main drivers of the observed shifts in Cladocera abundances.

Factors independent of DOC may have also favoured a change in the ratio of pelagic to littoral cladocerans, such as alterations to Cladocera habitats (e.g., destruction of macrophytes beds for aesthetic purposes), fish stocking, and other changes to predator composition and abundance (McQueen et al. 2001). Since pelagic cladocerans (such as daphniids and bosminids) occur in greater abundances in lakes with a larger pelagic area (Frey 1988; Hofmann 1998), increases in water depth may have favoured pelagic over littoral Cladocera, and other studies have documen- 
ted strong positive relationships between lake depth and pelagic cladocerans (e.g., Hofmann 1998, Bos \& Cumming 2003). Quinlan \& Smol (2002) found that south-central Ontario lakes that are hydrologically managed experienced increases in both lake depth and volume since pre-industrial times. Despite a reported increase in water depth in south-central Ontario lakes that are hydrologically managed (Quinlan \& Smol 2002), no apparent trend was observed when our study lakes were grouped into categories of hydrological management, and ranked according to change in pelagic:littoral ratios over time (Fig. 4). In addition, there were no significant relationships between the change in pelagic:littoral ratio over time and each five environmental variables $\left(\mathrm{Ca}, \mathrm{pH}, \mathrm{DOC}, \mathrm{SO}_{4}, \mathrm{Z}_{\max }\right.$; data not shown).

Within the pelagic community, we reported an ecologically important shift in daphniids and bosminids in most lakes over time. The modern $\mathrm{Ca}$ concentrations of lakes that had increased in daphniid relative abundances were significantly higher than the $\mathrm{Ca}$ concentrations of lakes that had declined in daphniids since pre-industrial times. This trend within the daphniid community was correlated to surface water $\mathrm{Ca}$ concentrations, but not to any other water quality variables examined (i.e. $\mathrm{pH}, \mathrm{DOC}, \mathrm{SO}_{4}, \mathrm{Z}_{\max }$ ). Daphniids have relatively high $\mathrm{Ca}$ requirements (Wærvågen et al. 2002; Jeziorski \& Yan 2006), because it is an important nutrient and a principal structural component of their carapace (Stevenson 1985), which they accumulate directly from the water through active transport (Cowgill 1976). Laboratory trials have demonstrated that the $\mathrm{Ca}$ content of daphniids is as much as $20 \mathrm{X}$ higher than that of non-daphniid cladocerans, including Bosmina spp. (Jeziorski \& Yan 2006), and a survival threshold for Daphnia pulex of 1.5-2.0 $\mathrm{mg} \mathrm{L}^{-1}$ has been documented in both laboratory and field studies in North America (Ashforth \& Yan 2008; Jeziorski et al. 2008). Ca is the dominant base cation in boreal shield lakes in Ontario (Watmough \& Dillon 2003), but its concentrations have been declining since the 1970s in poorly-buffered lakes in south-central Ontario as a result of acidic deposition, reduction in atmospheric calcium, forest harvesting, and forest regrowth (reviewed in Cairns \& Yan 2009). The observed decline in the relative abundances of Ca-rich daphniids over time in lakes with low $\mathrm{Ca}$ levels may reflect the general effect of declining $\mathrm{Ca}$ levels on daphniid populations in softwater lakes, as has been reported in Ontario and in other regions of North America (Jeziorski et al. 2008). Of the five study lakes with $\mathrm{Ca}$ concentrations below $1.5 \mathrm{mg}$ $\mathrm{L}^{-1}$, and correspondingly low relative abundances of Carich daphniid remains (Axe, Maggie, Pearceley, Pincher and Plastic, Fig. 3a), Plastic is the only lake for which there is a long-term record of zooplankton assemblage composition (since 1976). These data show a decline in all five common daphniid species know to be acid or
low-Ca sensitive since 1976 and a complete loss of the taxa in recent years. This is consistent with declines in ambient calcium concentrations and minimal changes in $\mathrm{pH}$ for this time period (Dr. N. Yan, York University, personal communication).

We also observed a shift to higher relative abundances of daphniids in 23 study lakes, which may be the result of several interactive processes that have influenced the cladoceran communities of these lakes, including notable changes in lake and soil geochemistry. For example, there have been considerable declines in total phosphorus (TP) concentrations over the last $\sim 30$ years in 8 long-term study lakes included in our lake dataset (Yan et al. 2008a) and since pre-industrial times, as inferred from diatom assemblages (Hall \& Smol 1996). The decline in food (phytoplankton) quality that may result from declines in TP may have provided larger daphniids with an advantage over other cladocerans, since larger daphniids have lower threshold food levels than smaller daphniids (Gliwicz 1990). However, Daphnia can be less successful than smaller cladocerans, such as Bosmina, due to reasons beyond the theory related to body size (DeMott \& Kerfoot 1982; DeMott 1982; Schulz \& Sterner 1999). Since there are limited data on the lipid and carbon to phosphorus ratios of algae in south-central Ontario lakes, it is difficult to make definitive statements about the role of phosphorus in daphniid and bosminid dynamics. Therefore, declining phosphorus levels does not entirely explain the increases in daphniid relative abundances, as threshold food level is only one of several factors that determine the advantages of daphniids over other species, such as Bosminids.

Although daphniids are acid sensitive organisms (Havens et al. 1993), daphniid relative abundances among the category groupings of $\mathrm{pH}$ were not significantly different (Fig. 6c), which may reflect the fairly narrow $\mathrm{pH}$ gradient of our study lakes (mean $\mathrm{pH}$ : $6.2 \pm 0.4$; range 5.2-6.8). The majority of lakes in this region of Ontario have acid deposition rates that have fallen below critical thresholds despite a reduction in acid deposition over the past two decades (Henrikson et al. 2002). In turn, biological recovery of zooplankton, including daphniids, from acid deposition has been documented in this region (Yan et al. 2008b, Gray \& Arnott 2009). Daphniid reproductive impairment has been shown to occur at pH 5.0 to 5.5 (Locke 1991; Sprules 1975; Keller et al. 1990), and the mean $\mathrm{pH}$ of our study lakes was above this $\mathrm{pH}$ level of reproductive impairment, which may help explain the lack of relationship between $\mathrm{pH}$ and changes in daphniids and bosminid relative abundances over time (Figs $5 \mathrm{c}, \mathrm{d}$ ). In contrast, however, this same dataset has shown a decline in daphniid size structure since pre-industrial times, where larger, acid sensitive daphniids (e.g., Daphnia mendotae) have been replaced by smaller, acid tolerant ones (e.g., D. catawba) possibly in response to lake acidi- 
fication (Korosi et al. 2010). This may imply that size structure within the daphniids is a more sensitive indicator of acidification than species composition.

As previously described, rising DOC levels have been observed in lakes in south-central Ontario (Keller et al. 2008), which may partially contribute to the increase in daphniids. In lakes with lowered light conditions, with a rise in DOC, daphniids may have a greater ability to elude visual predators, including planktivorous fish and predatory invertebrates, organisms that tend to prefer larger daphniids over other small cladocerans (Brooks \& Dodson 1965). When examining the available DOC measurements, our data set supports this hypothesis, as lakes with lower DOC concentrations $(<3$ $\mathrm{mg} \mathrm{L^{-1 }}$ ) showed a decline in daphniid relative abundances, while more dystrophic, high DOC lakes $(>7 \mathrm{mg}$ $\mathrm{L}^{-1}$ ) showed an increase in daphniid relative abundances. Although daphniids are also sensitive to ultraviolet radiation, they are not expected to benefit in this way from declining light levels, because lakes in this region of Ontario have sufficiently high DOC concentrations to prevent the harmful effects of UV penetration on Daphnia (>1-2 mg L L ${ }^{-1}$, Molot et al. 2004). However, as previously mentioned, water clarity has not significantly declined over the past three decades in eight intensively studied lakes from this dataset (MOE, DESC, unpublished data), indicating that, although differences in DOC concentrations may be a plausible explanation for increased daphniid relative abundances, it is difficult to determine what the causative factors are.

In addition to variations in lake chemistry, the fish communities in many Ontario Shield lakes have experienced important changes, including introductions of piscivorous bass, which have been linked to reduction in abundances of planktivorous fish (e.g., Mills \& Schiavonne 1982; McQueen et al. 1992; Demers et al. 2001). Size-selective predation by planktivorous fish is often considered to be one of the primary drivers of zooplankton size structure and the relative abundance of daphniids (Brooks \& Dodson 1965; Hobæk et al. 2002, Yan et al. 2001; Findlay et al. 2007). The possible reduction in planktivorous fish community pressure following the introductions of bass in some lakes in the 1900s (Kerr 2006) may favour larger Cladocera, including daphniids. Therefore, the observed increase in daphniid relative abundance may have been linked to changes in the fish communities in our subset of lakes over time. Daphniids tended to increase in relative abundance over time in lakes with low fish biomass (500-1000 $\left.\mathrm{g} \mathrm{net}^{-1}\right)$ and showed no change in lakes with high fish biomass $\left(>2000 \mathrm{~g} \mathrm{net}^{-1}\right)$, while the trends were less apparent at intermediate levels (1000-2000 $\left.\mathrm{g} \mathrm{net}^{-1}\right)$. Daphnia may tend to be most successful in lakes with low fish biomass (Carpenter \& Kitchell 1993), suggesting that there may be a release in predation pressure on daphniids in lakes with low fish biomass. Although suggestive of a regional trend, these relationships were not statistically significant for a subset of 24 study lakes where fish data were available. In addition, a reduced abundance of planktivorous fish would tend to favour an increase in Daphnia body size (Vander Zanden et al. 2004), which is contrary to the findings of Korosi et al. (2010) who showed that the maximum body size of Daphnia has actually decreased since pre-industrial times in these study lakes. Therefore, it does not appear that fish predation pressure has had a measurable impact on this cladoceran dataset.

Climate change is considered to be one of the greatest threats to the ecological integrity of aquatic communities across Canada (Schindler 2001). Increased mean annual temperatures resulting from climate warming have been reported in lakes across North America (e.g., Rühland, Paterson \& Smol 2008) including lakes in south-central Ontario (Palmer \& Yan unpublished data). Daphniids are sensitive to increases in lake water temperatures and recent studies have reported that climate warming has led to a possible increased growing season for cladocerans and other lake biota, including phytoplankton, due to reduced winter ice cover and a corresponding increased length of growing season (Keller 2007). An increased growing season may also present daphniids with an advantage over macroinvertebrate predators (Neill 1981), such as Chaoborus (Neill 1981). Although climate is known to influence the temporal coherence of zooplankton abundances (Rusak et al. 1999; Preston \& Rusak 2010), Yan et al. (2008b) found that mean cladoceran body size in seven of these study lakes was not correlated with several climate indices. In addition, Sweetman et al. (2008) found no consistent changes in planktonic cladoceran communities (bosminids and daphniids) over time in a top-bottom paleolimnological study of 50 lakes from the central Canadian arctic treeline region, an area that has experienced considerable warming over the last century (Chapin et al. 2000). It is possible that the climate-induced changes in the zooplankton communities noted in north temperate lakes have been outweighed by the myriad of chemical and biological changes discussed previously.

The presence of the invasive and predatory cladoceran, Bythotrephes longimanus, in eight study lakes must also be considered. Cladoceran species are vulnerable to Bythotrephes invasion because they are the preferred food item of this predatory species (Grigorovich et al. 1998; Schulz \& Yurista 1999). Typically, species assemblages of invaded lakes differ markedly from those of non-invaded lakes, with average species richness being 30\% higher in non-invaded than invaded lakes in Ontario (e.g., Boudreau \& Yan 2003; Yan et al. 2002; Strecker \& Arnott 2008). In some lakes, Bythotrephes has been shown to cause shifts in cladoceran community structure that favour larger Cladocera, such as daphniids (Wahlström \& Westman 1999). In the eight invaded lakes that we examined, modern cladoceran assemblages differed somewhat from assemblages 
that existed prior to invasion (e.g., pre-industrial times; Figs 2-3), but not in any directional way that differed from the non-invaded lakes.

\section{CONCLUSIONS}

This study provides the first detailed top-bottom paleolimnological analysis of sedimentary cladoceran assemblage composition from south-central Ontario lakes, which supports the growing body of research demonstrating that zooplankton communities on the southern Canadian Shield have undergone shifts in species composition over time (Yan et al. 1996, 2008b). Our results indicate that changes in the cladoceran communities since pre-industrial times are widespread across south-central Ontario lakes on the Precambrian Shield. Many of the reported chemical and biological changes occurring in these lakes, such as declining TP and increases in $\mathrm{pH}$ and piscivorous fish, should lead to an increase in the relative abundance of larger zooplankton such as daphniids, a trend that we do record, but only in those lakes with higher $\mathrm{Ca}$ concentrations. The opposite trend is observed in low Ca lakes, where, daphniid declines are occurring despite factors which may tend to favour Daphnia. Although the interpretation of the changes in the cladoceran communities over time are based on variations of environmental variables measured over the last $\sim 30$ years or estimated by paleolimnological analysis, our results emphasize that a multiple stressor context is necessary when interpreting ecological data from lakes on the Precambrian Shield region of south-central Ontario (Schindler 1998; Yan et al. 2008a), and also further demonstrate that sedimentary cladoceran remains are valuable tools in paleoenvironmental reconstructions, particularly for taxa with varying Ca-requirements.

\section{ACKKNOWLEDGEMENTS}

Thanks to C. Cheung, B. Clark, A. Jeziorski, M. Palmer and R. Ingram for their help with field work, Dr. K. Rühland for statistical assistance, the Ontario Ministry of the Environment (Dorset, Ontario) Dr. N. Yan and Michelle Palmer of York University for providing water chemistry data, and Dr. J. Gunn and G. Morgan of Laurentian University's Department of Biology for providing fish data. Thank you also to two anonymous reviewers for their valuable comments. This project was funded by an Ontario Ministry of the Environment Best in Science Grant and NSERC grants to JPS.

\section{REFERENCES}

Ashforth, D. \& N.D. Yan. 2008. The interactive effects of falling calcium concentrations and rising temperatures on Daphnia pulex life table parameters at low and high food concentrations. Limnol. Oceanogr., 53: 420-432.

Bos, D.G. 2001. Sedimentary cladoceran remains, a key to interpreting past changes in nutrient and trophic interactions. PhD thesis, Queen's University, Kingston, Ontario, Canada.
Bos, D.G. \& B.F. Cumming. 2003. Sedimentary cladoceran remains and their relationship to nutrients and other limnological variables in 53 lakes from British Columbia, Canada. Can. J. Fish. Aquat. Sci., 60: 1177-1189.

Boudreau, S.A. \& N.D. Yan. 2003. The differing crustacean zooplankton communities of Canadian Shield lakes with and without the nonindigenous zooplanktivore Bythotrephes longimanus. Can. J. Fish. Aquat. Sci., 60: 1307-1313.

Bray, J.R. \& J.T. Curtis. 1957. An ordination of the upland forest communities of southern Wisconsin. Ecol. Monographs, 27: 325-349.

Brooks, J.L. \& S.I. Dodson. 1965. Predation, body size, and composition of plankton. Science, 150: 26-35.

Cairns, A. \& N.D. Yan. 2009 A review of the influence of low ambient calcium concentrations on daphniids, gammarids and crayfish. Env. Reviews, 17: 67-79.

Carpenter, S.R. \& J.F. Kitchell. 1993. The trophic cascade in lakes. Cambridge University Press: 385 pp.

Chapin, S.F. III, A.D. McGuire, J. Randerson, R. Pielke, D. Baldocchi, S.E. Hobbie, N. Roulet, W. Eugster, E. Kasischke, E.B. Rastetter, S.A. Zimov, \& S.W. Running. 2000. Arctic and boreal ecosystems of western North America as components of the climate system. Glob. Change Biol., 6 Suppl. 1: 211-223.

Chengalath, R. \& B.J. Hann. 1981a. Two new species of Alona (Chydoridae, Cladocera) from western Canada. Can. J. Zool., 59: 377-389.

Chengalath, R. \& B.J. Hann. 1981b. A new Species of Chydorus (Cladocera: Chydoridae) from Ontario Canada. Trans. Amer. Micros. Soc., 100(3): 229-238.

Christensen, M.R., M.D. Graham, R.D. Vinebrooke, D.L. Findlay, M.J. Paterson \& M.A. Turner. 2006. Multiple anthropogenic stressors cause ecological surprises in boreal lakes. Glob. Change Biol., 12: 1-7.

Clarke, K.R. 1993. Non-parametric multivariate analyses of changes in community structure to environmental variables. Aust. J. Ecol., 18: 117-143.

Clarke, K.R. \& R.H. Green. 1988. Statistical design and analysis for a "biological effects" study. Mar. Ecol. Prog. Ser., 46: 213-226.

Clarke, K.R. \& R.M. Warwick. 1994. Change in Marine Communities: An Approach to Statistical Analysis and Interpretation. Natural Environment Research Council, UK: $144 \mathrm{pp}$.

Clarke, K.R. \& R.M. Warwick. 2001. Change in Marine Communities: An Approach to Statistical Analysis and Intepretation. 2nd ed. Primer-E, Plymouth: $172 \mathrm{pp}$.

Clerk, S., R. Hall, R. Quinlan \& J.P. Smol. 2000. Quantitative inferences of past hypolimnetic anoxia and nutrient levels from a Canadian Precambrian Shield lake. J. Paleolimnol., 23: 319-336.

Colbourne, J.K. \& P.D.N. Hebert. 1996. The systematics of North American Daphnia (Crustacea: Anomopoda): a molecular phylogenetic approach. Phil. Trans. R. Soc. Lond. B, 351: 349-360.

Cowgill, U.M. 1976. The chemical composition of two species of Daphnia, their algal food and their environment. Sci. Total Environ., 6(1): 79-102.

De Melo, R. \& P.D.N. Hebert. 1994. A taxonomic re-evaluation of the North American Bosminidae. Can. J. Zool., 72: 1808-1825.

Demers, E., D.J. McQueen, C.W. Ramcharan \& A. PérezFuentetaja. 2001. Did piscivores regulate changes in fish community structure? Advanc. Limnol., 56: 49-80.

DeMott, W.R. 1982. Feeding selectivities and relative ingestion rates of Daphnia and Bosmina. Limnol. Oceanogr., 27: 518-527.

DeMott, W.R. \& C. Kerfoot. 1982. Competition among cladocerans: nature of the interaction between Bosmina and Daphnia. Ecology, 63: 1949-1966. 
DeSellas, A.M., A.M. Paterson, J.N. Sweetman \& J.P. Smol. 2008. Cladocera assemblages from the surface sediments of south-central Ontario (Canada) lakes and their relationships to measured environmental variables. Hydrobiologia, 600: 105-119.

Dillon, P.J., D.S. Jeffries, W. Snyder, R. Reid, N.D. Yan, D. Evans, J. Moss \& W.A. Scheider. 1978. Acidic precipitation in south-central Ontario: recent observations. J. Fish. Res. Board Can., 35: 809-815.

Drake, J.M., K.L.S. Drury, D.M. Lodge, A. Blukacz, N.D. Yan \& G. Dwyer. 2006. Demographic stochasticity, environmental variability, and windows of invasion risk for Bythotrephes longimanus in North America. Biol. Invasions, 8: 843-861.

Eimers, M.C., S.A. Watmough, A.M. Paterson, P.J. Dillon \& H. Yao 2009. Long-term declines in phosphorus export from forested catchments in south-central Ontario. Can. J. Fish. Aquat. Sci., 66: 1682-1692.

Findlay, K., B.E. Beisner, A. Patoine \& B. Pinel-Alloul 2007. Regional ecosystem variability drives the relative importance of bottom-up and top-down factors for zooplankton size spectra. Can. J. Fish. Aquat. Sci., 64: 516-529.

Flössner, D. \& K. Kraus. 1977. On the variability and taxonomy of Pleuroxus denticulatus Birge (Cladocera: Chydoridae). J. Fish. Res. Board Can., 34: 463-476.

Frey, D.G. 1959. The taxonomic and phylogenetic significance of the head pores of the Chydoridae (Cladocera). Int. Revue ges. Hydrobiol., 44: 27-50.

Frey, D.G. 1962. Cladocera from the Eemian Interglacial of Denmark. J. Paleontol., 36: 1133-1154.

Frey, D.G. 1965. Differentiation of Alona costata Sars from two related species (Cladocera, Chydoridae). Crustaceana, 8: 159-173.

Frey, D.G. 1980. On the plurality of Chydorus sphaericus (OF Muller) (Cladocera, Chydoridae), and the designation of a neotype from Sjaelso, Denmark. Hydrobiologia, 69: 83-123.

Frey, D.G. 1985. A new species of the Chydorus sphaericus group (Cladocera, Chydoridae) from western Montana. Int. Revue ges. Hydrobiol., 70: 3-20.

Frey, D.G. 1986. Cladoceran Analysis-Handbook of Holocene Palaeoecology and Palaeohydrology. B.E. Berglund (Ed.), John Wiley and Sons, New York: 667-692 pp.

Frey, D.G. 1987. The taxonomy and biogeography of the Cladocera. Hydrobiologia, 145: 5-17.

Frey, D.G. 1988. Littoral and offshore communities of diatoms, cladocerans and dipterous larvae, and their interpretation in paleolimnology. J. Paleolimnol., 1: 179-191.

Futter, M.N. 2003. Patterns and trends in Southern Ontario lake ice phenology. Environ. Monit. Assess., 88: 431-444.

Glew, J. 1988. A portable extruding device for close interval sectioning of unconsolidated core samples. J. Paleolimnol., 1: 235-239.

Glew, J. 1989. A new trigger mechanism for sediment samplers. J. Paleolimnol., 2: 241-243.

Glew, J. 1991. Miniature gravity corer for recovering short sediment cores. J. Paleolimnol., 5: 285-287.

Gliwicz, Z.M. 1990. Food thresholds and body size in cladocerans. Nature, 343: 638-640.

Gray, D.G. \& S.E. Arnott. 2009. Recovery of acid damaged zooplankton communities: measurement, extent, and limiting factors. Environ. Rev., 17: 81-99.

Grigorovich, I.A., O.V. Pashkova, Y.F. Gromova \& C.D.A. van Overdijk. 1998. Bythotrephes longimanus in Commonwealth of Independent states: variability, distribution and ecology. Hydrobiologia, 379: 183-198.

Gyllström, M., L.-A. Hannson, E.P. Jeppesen, F. GarciaCriado, E. Gross, K. Irvine, T. Kairesalo, R. Kornijow, M.R. Miracle, M. Nykänen, T. Nõges, S. Romo, D. Stephen, E. Van Donk \& B. Moss. 2005. The role of climate in shaping zooplankton communities of shallow lakes. Limnol. Oceanogr., 50: 2008-2021.
Hall, R.I. \& J.P. Smol. 1996. Paleolimnological assessment of long-term water-quality changes in south-central Ontario lakes affected by cottage development and acidification. Can. J. Fish. Aquat. Sci., 53: 1-17.

Hann, B.J. 1982. Two new species of Eurycercus (Bullatifrons) from eastern North America (Chydoridae, Cladocera). Taxonomy, ontogeny, and biology. Int. Revue ges. Hydrobiol., 67: 585-610.

Havens, K.E., N.D. Yan \& W. Keller. 1993. Lake acidification: effects on crustacean zooplankton populations. Environ. Sci. Technol., 27: 1621-1624.

Hebert, P.D.N. 1995. The Daphnia of North America: An illustrated fauna. Macromedia CD ROM. University of Guelph, Guelph, Ontario, Canada.

Henrikson, A., P.J. Dillon \& J. Aherne. 2002. Critical loads of acidity for surface waters in south-central Ontario, Canada: regional application of the Steady-State Water Chemistry (SSWC) model. Can. J. Fish. Aquat. Sci., 59: 1287-1295.

Hobæk, A., M. Manca \& T. Andersen. 2002. Factors influencing species richness in lacustrine zooplankton. Acta Oecol., 23: 155-163.

Hofmann, W. 1998. Cladocerans and chironomids as indicators of lake level changes in north temperate lakes. $J$. Paleolimnol., 19: 55-62.

Jeffries, D.S. \& W.R. Snyder. 1983. Geology and geochemistry of the Muskoka-Haliburton study area. Ontario Ministry of Environment, Data Report DR 83/2.

Jeppesen, E.P., J.P. Jensen, C. Jensen, B. Faafeng, D.O. Hessen, M. Søndergaard, T. Lauridsen, P. Brettum \& K. Christoffersen. 2003. The impact of nutrient state and lake depth on top-down control in the pelagic zone of lakes: a study of 466 lakes from the temperate zone to the Arctic. Ecosystems, 6: 313-325.

Jeziorski, A. \& N.D. Yan. 2006. Species identity and aqueous calcium concentrations as determinants of calcium concentrations of freshwater crustacean zooplankton. Can. J. Fish. Aquat. Sci., 63: 1007-1013.

Jeziorski, A., N.D. Yan, A.M. Paterson, A.M. DeSellas, M.A. Turner, D.S. Jeffries, B. Keller, R.C. Weeber, D.K. McNicol, M.E. Palmer, K. McIver, K. Arseneau, B.K. Ginn, B.F. Cumming \& J.P. Smol. 2008. The widespread threat of calcium decline in fresh waters. Science, 322: 13741377.

Keller, W. 2007. Implications of climate warming for Boreal Shield lakes: a review and synthesis. Env. Reviews, 15: 99112.

Keller, W. \& N.D. Yan. 1998. Biological recovery from lake acidification: zooplankton communities as a model of patterns and processes. Restor. Ecol., 6: 364-375.

Keller, W., A.M. Paterson, K.A. Somers, P.J. Dillon, J. Heneberry \& A. Ford. 2008. Relationships between dissolved organic carbon concentrations, weather, and acidification in small Boreal Shield lakes. Can. J. Fish. Aquat. Sci., 65: 786-795.

Keller, W., N.D. Yan, K.E. Holtze \& J.R. Pitblado. 1990. Inferred effects of lake acidification on Daphnia galeata mendotae. Environ. Sci. Technol., 24: 1259-1261.

Kerr, S.J. 2006. An historical review of fish culture, stocking and fish transfers in Ontario, 1865-2004. Fish and Wildlife Branch, Ontario Ministry of Natural Resources, Peterborough, Ontario: 224 pp.

Kirchner, J.W. \& E. Lydersen, E. 1995. Base cation depletion and potential long term acidification of Norwegian catchments. Environ. Sci. Technol., 29: 1953-1960.

Korhola, A. \& M. Rautio. 2001. 2. Cladocera and other branchiopod crustaceans. In: Smol, J.P., H.J.B. Birks \& W.M. (Eds), Last Tracking Environmental Change Using Lake Sediments. Vol. 4, Zoological Indicators. Kluwer Academic Publishers, Dordrecht, The Netherlands. pp. 5-41. 
Korosi, J.B., A.M. Paterson, A.M. DeSellas \& J.P. Smol. 2010. A comparison of pre-industrial and present-day changes in Bosmina and Daphnia size structure from softwater Ontario lakes. Can. J. Fish. Aquat. Sci., 67: 754-762.

Korovchinsky, N.M. 1992. Sididae \& Holopediidae. Guides to the identification of the microinvertebrates of the continental waters of the world, 3. SPB Academic Publishers, The Hague: 82 pp.

Kurek, J., J.B. Korosi, A. Jeziorski \& J.P. Smol. 2010. Establishing reliable minimum count sizes for cladoceran microfossils sampled from lake sediments. J. Paleolimnol., 44(2): 603-612.

Little, J.L. \& J.P. Smol. 2001. A chironomid-based model for inferring late-summer hypolimnetic oxygen in Southeastern Ontario lakes. J. Paleolimnol., 26: 259-270.

Locke, A. 1991. Zooplankton responses to acidification: a review of laboratory bioassays. Water, Air, and Soil Pollution, 60: 135-148.

McQueen, D.J., E.L. Mills, J.L. Forney, M.R.S. Johannes \& J.R. Post. 1992. Trophic level relationships in pelagic food webs: comparisons derived from long-term data sets for Oneida Lake, New York (USA), and Lake St. George, Ontario (Canada). Can. J. Fish. Aquat. Sci., 49: 1588-1596.

McQueen, D.J., C.W. Ramcharan, N.D. Yan, E. Demers, A. Pérez-Fuentetaja \& P.J. Dillon. 2001. The Dorset food web piscivore manipulation project-Part 1: objectives, methods, the physical-chemical setting. Advanc. Limnol., 56: $1-21$.

Megard, R.O. 1967. Three new species of Alona (Cladocera, Chydoridae) from the United States. Int. Revue ges. Hydrobiol., 52: 37-50.

Michalski, M.F.P., M.G. Johnson \& D.M. Veal. 1973. Muskoka Lakes Water Quality Evaluation. Ontario Ministry of the Environment. Data Report DR 73/3.

Mills, E.L. \& A. Schiavone. 1982. Evaluation of fish communities through assessment of zooplankton populations and measures of lake productivity. N. Am. J. Fish. Manage, 2(1): 14-27.

Molot, L.A. \& P.J. Dillon. 2008. Long-term trends in catchment export and lake concentrations of base cations in the Dorset study area, central Ontario. Can. J. Fish. Aquat. Sci., 65: 809-820.

Molot, L.A., W. Keller, P.R. Leavitt, R.D. Robarts, M.J. Waiser, M.T. Arts, T.A. Clair, R. Pienitz, N.D. Yan, D.K. McNicol, Y.T. Prairie, P.J. Dillon, M. Macrae, R. Bello, R.N. Nordin, P.J. Curtis, J.P. Smol \& M.S.V. Douglas. 2004. Risk analysis of dissolved organic matter-mediated ultraviolet B exposure in Canadian inland waters. Can. J. Fish. Aquat. Sci., 61: 2511-2521.

Monteith, D.T., J.L. Stoddard, C.D. Evans, H.A. de Wit, M. Forsius, T. Høgåsen, A. Wilander, B.L. Skjelkvåle, D.S. Jeffries, J. Vuorenmaa, B. Keller, J. Kopácek \& J. Vesely. 2007. Dissolved organic carbon trends resulting from changes in atmospheric deposition chemistry. Nature, 450: 537-541.

Neill, W.E. 1981. Impact of Chaoborus predation upon the structure and dynamics of a crustacean zooplankton community. Oecologia, 48: 164-177.

Paterson, A.M., B.F. Cumming, J.P. Smol \& R.I. Hall. 2001. Scaled chrysophytes as indicators of water quality changes since pre-industrial times in the Muskoka-Haliburton region, Ontario, Canada. Can. J. Fish. Aquat. Sci., 58: 2468-2481.

Paterson, A.M., B.F. Cumming, J.P. Smol \& R.I. Hall. 2004. Marked recent increases of colonial scaled chrysophytes in boreal shield lakes: implications for the management of taste and odour events. Freshwat. Biol., 49: 199-207.

Paterson, A.M., J.G. Winter, K.H. Nicholls, B.J. Clark, C.W. Ramcharan, N.D. Yan \& K.M. Somers. 2008. Long-term changes in phytoplankton composition in seven Canadian Shield lakes in response to multiple anthropogenic stressors. Can. J. Fish. Aquat. Sci., 65: 847-861.
Paterson, M.J. 1994. Paleolimnological reconstruction of recent changes in assemblages of Cladocera from acidified lakes in the Adirondack Mountains (New York). J. Paleolimnol., 11: 189-200.

Pennak, R.W. 1989. Freshwater Invertebrates of the United States. 3rd ed. John Wiley, New York, N.Y., U.S.A: 628 pp.

Preston, N.D. \& J.A. Rusak. 2010. Homage to Hutchinson: does inter-annual climate variability affect zooplankton density and diversity? Hydrobiologia, 653: 165-177.

Quinlan, R. \& J.P. Smol. 2002. Regional assessment of longterm hypolimnetic oxygen changes in Ontario (Canada) shield lakes using subfossil chironomids. J. Paleolimnol., 27: 249-260.

Quinlan, R., J.P. Smol \& R.I. Hall. 1998. Quantitative inferences of past hypolimnetic anoxia in south-central Ontario lakes using fossil midges (Diptera: Chironomidae). Can. J. Fish. Aquat. Sci., 55: 587-596.

Roff, J.C. \& R.E. Kwiatkowski. 1977. Zooplankton and zoobenthos communities of selected northern Ontario lakes of different acidities. Can. J. Zool., 55: 899-911.

Rühland, K., A.M. Paterson \& J.P. Smol. 2008. Hemisphericscale patterns of climate-related shifts in planktonic diatoms from North American and European lakes. Glob. Change Biol, 15: 2740-2754.

Rusak, J.A., N.D. Yan \& K.M. Somers. 2008. Regional climatic drivers of synchronous zooplankton dynamics in north-temperate lakes. Can. J. Fish. Aquat. Sci., 65: 847-861.

Rusak, J.A., N.D. Yan, K.M. Somers \& D.J. McQueen 1999. The temporal coherence of zooplankton population abundances in neighboring north-temperate lakes. Am. Nat., 153: 46-58.

Schindler, D.W. 1998. A dim future for boreal waters and landscapes. BioScience, 48: 157-164.

Schindler, D.W. 2001. The cumulative effects of climate warming and other human stresses on Canadian freshwaters in the new millennium. Can. J. Fish. Aquat. Sci., 58: $18-29$.

Schulz, K.L. \& R.W. Sterner 1999. Phytoplankton phosphorus limitation and food quality for Bosmina. Limnol. Oceanogr., 44: 1549-1556.

Schulz, K.L. \& P.M. Yurista. 1999. Implications of an invertebrate predator's (Bythotrephes cederstroemi) atypical effects on a pelagic zooplankton community. Hydrobiologia, 380: 179-193.

Smirnov, N.N. 1974, Fauna of the U.S.S.R. Crustacea. Chydoridae. Vol. 1, n. 2. Israel Program for Scientific Translations, Jerusalem: $644 \mathrm{pp}$.

Smirnov, N.N. 1996. Cladocera: the Chydorinae and Sayciinae (Chydoridae) of the world. Guides to the identification of the microinvertebrates of the continental waters of the world, 11. SPB Academic Publishing, The Hague, Netherlands: $197 \mathrm{pp}$

Smol, J.P. 2008 Pollution of Lakes and Rivers: a Paleoenvironmental Perspective. $2^{\text {nd }}$ ed. Blackwell Publishing, Oxford: $383 \mathrm{pp}$.

Smol, J.P. 2010. The power of the past: Using sediments to track the effects of multiple stressors on lake ecosystems. Freshwat. Biol., 55 (Suppl. 1): 43-59.

Sokal, R.R. \& F.J. Rohlf. 1981. Biometry. The principles and practice of statistics in biological research. $2^{\text {nd }}$ ed. W.H. Freeman and Company, New York: 859 pp.

Sprules, W.G. 1975. Midsummer crustacean zooplankton communities in acid-stressed lakes. J. Fish. Res. Board Can., 32: 389-395.

Stansfield, J.H., M.R. Perrow, L.D. Tench, A.J.D. Jowitt \& A.A.L. Taylor. 1997. Submerged macrophytes as refuges for grazing Cladocera against fish predation: observations on seasonal changes in relation to macrophyte cover and predation pressure. Hydrobiologia, 342/343: 229-240.

Stevenson, J.R. 1985. Dynamics of the integument. In: Bliss, D.E. \& L.H. Mantel (Eds), The Biology of Crustacea. Vol. 
9, Integument, pigments and hormonal processes. Academic Press, New York: 1-42.

Stoddard, J.L., D.S. Jeffries, A. Lükewille, T.A. Clair, P.J. Dillon, C.T. Driscoll, M. Forsius, M. Johannessen, J.S. Kahl, J.H. Kellogg, A. Kemp, J. Mannio, D.T. Monteith, P.S. Murdoch, S. Patrick, A. Rebsdorf, B.L. Skjelkvale, M.P. Stainton, T. Traaen, H. van Dam, K.E. Webster, J. Wieting \& A. Wilander. 1999. Regional trends in aquatic recovery from acidification in North America and Europe. Nature, 401: 575-578.

Strecker, A.L. \& S.E. Arnott. 2008. Invasive predator, Bythotrephes, has varied effects on ecosystem function in freshwater lakes. Ecosystems, 11: 490-503.

Suchy, K.D. \& B.J. Hann. 2007. Using microfossil remains in lake sediments to examine the invastion of Eubosmina coregoni (Cladocera, Bosminidae) in Lake of the Woods, Ontario, Canada. J. Great Lakes Res., 33: 867-874.

Sweetman, J.N., E. La Face, K.M. Rühland \& J.P. Smol. 2008. Evaluating the response of Cladocera to recent environmental changes in lakes from the central Canadian Arctic treeline region. Arct. Antarct. Alp. Res, 40: 584-591.

Taylor, D.J., C.R. Ishikane \& R.A. Haney. 2002. The systematics of Holarctic Bosminids and a revision that reconciles molecular and morphological evolution. Limnol. Oceanogr., 47: 1486-1495.

Taylor, D., C. Dalton, M. Leira, P. Jordan, G. Chen, L. LeónVintró, K. Irvine, H. Bennion, T. Nolan. 2006. Recent histories of six productive lakes in the Irish Ecoregion based on multiproxy palaeolimnological evidence. Hydrobiologia, 571: 237-259.

Vander Zanden, M.J., J.D. Olden, J.H. Thorne \& N.E. Mandrak. 2004. Predicting the occurrence and impact of bass introductions in north-temperate lakes. Ecol. Appl., 14: $132-148$.

Wærvågen, S.B., N.A. Rukke \& D.O. Hessen. 2002. Ca content of crustacean zooplankton and its potential role in the species distribution. Freshwat. Biol., 47: 1866-1878.

Wahlström, E. \& E. Westman. 1999. Planktivory by the predacious cladoceran Bythotrephes longimanus: effects on zooplankton size structure and abundance. Can. J. Fish. Aquat. Sci., 56: 1865-1872.

Walseng, B., D.O. Hessen, G. Halvorsen \& A.K. Schartau. 2006. Major contribution from littoral crustaceans to zooplankton species richness in lakes. Limnol. Oceanogr., 51: 2600-2606.

Received: July 2010

Accepted: October 2010
Watmough, S.A. \& P.J. Dillon. 2003. Calcium losses from a forested catchment in south-central Ontario, Canada. Environ. Sci. Technol., 37: 3085-3089.

Wilkinson, A.N., R.I. Hall \& J.P. Smol. 1999. Chrysophyte cysts as paleolimnological indicators of environmental change due to cottage development and acidic deposition in the Muskoka-Haliburton region, Ontario, Canada. $J$. Paleolimnol., 22: 17-39.

Wissel, B., W.J. Boeing \& C.W. Ramcharan. 2003. Effects of water color on predation regimes and zooplankton assemblages in freshwater lakes. Limnol. Oceanogr., 48: 19651976.

Witty, L.M. 2004. Practical guide to identifying freshwater crustacean zooplankton. Cooperative Freshwater Ecology Unit, Department of Biology, Laurentian University. Sudbury, Ontario: $60 \mathrm{pp}$.

Yan, N.D., R. Girard \& S. Boudreau. 2002. An introduced invertebrate predator (Bythotrephes) reduces zooplankton species richness. Ecol. Lett., 5: 481-485.

Yan, N.D., A.M. Paterson, K.M. Somers \& W.A. Scheider. 2008a. An introduction to the Dorset special issue: transforming understanding of factors that regulate aquatic ecosystems on the southern Canadian Shield. Can. J. Fish. Aquat. Sci., 65: 781-785.

Yan, N.D., W. Keller, K.M. Somers, T.W. Pawson \& R.E. Girard. 1996. Recovery of crustacean zooplankton communities from acid and metal contamination: comparing manipulated and reference lakes. Can. J. Fish. Aquat. Sci., 53: 1301-1327.

Yan, N.D., A. Pérez-Fuentetaja, C.W. Ramcharan, D.J. McQueen, E. Demers \& J.A. Rusak. 2001. Changes in the crustacean zooplankton communities of Mouse and Ranger Lakes-Part 6 of the Dorset Food Web Piscivore Manipulation Project. Advanc. Limnol., 56: 127-150.

Yan, N.D., K.M. Somers, R.E. Girard, A.M. Paterson, W. Keller, C.W. Ramcharan, J.A. Rusak, R. Ingram, G.E. Morgan \& J.M. Gunn. 2008b. Long-term trends in zooplankton of Dorset, Ontario, lakes: the probable interactive effects of changes in $\mathrm{pH}$, total phosphorus, dissolved organic carbon, and predators. Can. J. Fish. Aquat. Sci., 65: 862-877.

Zhang, J., J. Hudson., R. Neal, J. Serada, T. Clair, M. Turner, D. Jeffries, P. Dillon, L. Molot, K. Somers \& R. Hesslein. 2010. Long-term patterns of dissolved organic carbon in lakes across eastern Canada: Evidence of a pronounced climate effect. Limnol. Oceanogr., 55: 30-42. 